\title{
IS AN INTERTEMPORAL MODEL OF THE CURRENT ACCOUNT VALID FOR EAST ASIAN COUNTRIES? EVIDENCE FROM STRUCTURAL VAR
}

\author{
Chen-Yin KUO \\ Tung Fang Design Institute, No.110, Tungfang Rd., \\ Hunei Township, Kaohsiung 82941, Taiwan, R.O.C. \\ E-mail:monkey5709@hotmail.com \\ Received 13 July 2013; accepted 08 September 2014
}

\begin{abstract}
This paper aims to examine the validity of present-value model of current account (PVMCA) by analyzing dynamic responses of variables in PVMCA to structural shocks. In place of the cross-equation restriction tests used in existing research, we adopted a structural vector autoregression framework and obtain three findings. First, evidences from 4 East Asian countries supported the intertemporal theoretical expectation that country-specific transitory shocks significantly affect current accounts, whereas the effects of global and country-specific permanent shocks are negligible. Second, countryspecific transitory shocks that primarily affected current account variance dominate net output variation. Third, global permanent and transitory shocks mainly affecting variances in world interest rates and exchange rates secondarily explain current account variance. Therefore, three explanatory variables of PVMCA sufficiently explain current account variations. In practice, investors can use the PVMCA to forecast changes in current accounts; they further judge business risks stemming from the changes, and adjust their security portfolio.
\end{abstract}

Keywords: current account, structural vector autoregression, global shocks, countryspecific shocks, stochastic world interest rate, exchange rate.

JEL Classification: C32, F32.

\section{Introduction}

In the late nineteenth century, several scholars proposed the intertemporal approach to current account, and developed basic intertemporal present value model of the current account (PVMCA). According to the model, current account is present value of expected net output growth (Buiter 1981; Obstfeld 1996; Sachs 1981). The PVMCA generally used cross-equation restriction tests proposed by Campbell (1987) and Campbell and Shiller (1987); these tests failed to prove the validity of PVMCA completely. Six of the G-7 countries were not supported by restrictions, namely, the PVMVA model was not supported by G-7 data (Ghosh 1995; Otto 1992; Sheffrin, Woo 1990). A modified PVMCA thus was proposed. Bergin and Sheffrin (2000) determined that stochastic 
real interest rates and exchange rates contribute to forecasting ability of PVMCA for the United Kingdom, Canada, and Australia. Nason and Rogers (2002) asserted that the failure of basic PVMCA explaining current account variation resulted from a lack of stochastic interest rates. Blankenau et al. (2001) and Nason and Rogers (2006) insisted on importance of stochastic rates when exploring fluctuations in Canadian current account. Iscan (2003) and Gruber (2004) provided evidences on modified PVMCA, whereas certain studies have been unsatisfactory (Moccero 2007; Kano 2008) ${ }^{1}$. Recent studies are observed. Hoffmann (2013) incorporated stochastic exchange rates and saving factors to develop a present value model of current accounts. Cerrato et al. (2014) found that some countries validate theoretical predictions of a current account model while others fail. By incorporating the ratio of private sector financing to GDP, Brissimis et al. (2012) verify a modified current account model. Ca'Zorzi and Rubaszek (2012) found an intertemporal model to explain current account configuration in the euro area. Baharumshah and Ismail (2012) concluded that present value of future net output reflects current account evolution in Thailand. Luo et al. (2012) incorporated two types of uncertainty to improve model's predictions for current account persistence in small open economies. Aizenman and Jinjarak (2014) applied the present value model of current account to study current account and credit growth patterns.

Since global oil crisis of the 1970s, researchers started to investigate how information shocks affect current accounts. They used structural vector autoregression (SVAR) and Blanchard and Quah's (1989) method to identify economic shocks and examine dynamic responses of current accounts to various shocks, determining whether the responses agree with theoretical predictions. An agreement between predicted and experimental responses indicates that a country transitory shock affects current accounts, whereas a country permanent shock and global shocks have little effect on current accounts because the latter affect all countries equally (Nason, Rogers 2002; Obstfeld, Rogoff 1995). A temporary increase in national income forces citizens to lend to the rest of world, and induces an increase in current accounts. If this rise becomes permanent, current accounts should not change because citizens need not smooth their consumption by lending to other countries. Against previous results, current account surplus of Chinese in Hoffmann (2013) was driven by global shocks. Schubert (2014) investigated dynamic effects of oil price shocks and their impact on the current account. Narayan (2013) employ a structural VAR model to explore the similar issue.

Three aspects of existing literatures need to be clarified. First, current evidences on intertemporal theory and PVMCA are mixed. Certain studies confirmed that countryspecific shocks are a crucial source of current account variations, supporting theoretical

\footnotetext{
${ }^{1}$ Iscan (2003) and Gruber (2004) provided evidence indicating that non-time separable utility functions (i.e., habit formation and durability in consumption) improved the ability of the basic PVM to match current account data. Moccero (2007) reported that a new intertemporal PVMCA incorporating exchange rates and world interest rates, and applying a VAR framework, failed to explain the actual current account in Argentina because the country lacks an international financial system and thus suffers from international payments balances crisis.
} 
predictions $^{2}$, whereas others proposed that global shocks play a crucial role ${ }^{3}$. Second, in addition to investigate which shock significantly affects current accounts, few studies further prove the validity of PVMCA; this is because that intertemporal model lacks sufficient variable information (Nason, Rogers 2002). Third, Kano's (2008) second puzzle ${ }^{4}$ indicated that net output in PVMCA failed to explain current account variations.

The aforementioned gaps in extant research inspired the current study. First purpose is to explore which shock primary affects current account variations. Second purpose is further to investigate whether shocks primarily explaining current account variations also dominate variations in net output, real exchange rates, and world interest rates, or all the three. If such a result is found, I can prove the validity of PVMCA because the variables of PVMCA contain sufficient information to explain current accounts variations. Furthermore, the SVAR is a potentially useful approach in PVMCA literature because it can attribute sources of variable dynamic variation to global or country-specific shocks. Based on the PVMCA and intertemporal theory, we estimated SVAR and derive impulse response function (IRF) to analyze dynamic response of current accounts to four shocks over multiple periods, using forecast error variance decomposition (FEVD) to identify percentages of current account variances produced by structural shocks.

This paper's empirical approach differs from previous literatures in four ways. First, in lieu of the cross-equation restriction tests used in previous studies, I adopted SVAR framework to examine the validity of PVMCA modified by Hoffmann (2013). Second, in contrast to industrialized countries that exhibit chronic deficits, this work explores Asian economies with current account surpluses ${ }^{5}$. Third, I defined country-specific and global shocks based on the effect scope rather than regional source used by Kano $(2008)^{6}$. Fourth, considering shock shifts stemming from several events $\mathrm{s}^{7,8}$, data spanned from 1963 to 2012 were divided into two subsets: developing and developed countries.

${ }^{2}$ A line of research supported country-specific shocks. Some reports include Obstfeld and Rogoff (1995), Glick and Rogoff (1995), Nason and Rogers (2002), Lee and Chinn (2006), Kano (2008), and Bussière et al. (2010).

${ }^{3}$ The existing research contradicting the conventional view supported the influence of global shocks on current accounts, for example, Elliott and Fatas (1996), Souki and Enders (2008), and Hoffmann (2013).

${ }^{4}$ The second puzzle is that a country-transitory shock that has no significant effect on net output dominates fluctuations in the current account in the short and long run (Kano 2008: 774).

${ }^{5}$ In 2004, Japan exhibited a current account surplus amounting to $3.7 \%$ of its GDP. The ASEAN-4 economies (Taiwan, Singapore, Hong Kong, and South Korea) exhibited a surplus of \$28 billion, accounting for $7.1 \%$ of their GDP (Kim, Lee 2007). China, particularly, has lately exhibited a persistent high current account surplus, which is regarded as a main source of global imbalance and a mirror image of the persistent U.S. trade deficit (Hoffmann 2013).

${ }^{6}$ This paper adopted the definition of Souki and Enders's (2008) study, which developed an identification scheme considering that a country-specific shock had no contemporaneous effects on other countries. By contrast, global shocks could affect several countries simultaneously.

${ }^{7}$ For example, the 1997 Asian financial crisis, the 2007 U.S. subprime mortgage crisis, and the 2009 European sovereign debt crisis.

${ }^{8}$ Emerging market economies in East Asia exhibited great current account surpluses, particularly since the 1997-1998 Asian financial crises (Kim, Lee 2007). 
The findings suggest that first, Hong Kong, India, Taiwan and Singapore support hypotheses $\mathrm{H} 1$ and $\mathrm{H} 2$, showing that country-specific transitory shocks significantly affect current accounts, whereas effects of other shocks are ambiguous. Second, 4 countries' findings indicate that a country-specific transitory shock that primarily explain current account variances dominate net output variation, providing a resolution of Kano's (2008) second puzzle (2008: 774) in favor of hypotheses H3 and H4. Global-permanent and transitory shocks that secondarily explain current accounts dominate fluctuations in world interest rates and exchange rates. Three shocks explain most of current account variance, implying that explanatory variables of PVMCA contain sufficient information to explain current account variations, further confirming the validity of the PVMCA. Third, evidences from 6 Asian countries consistently support the assumption that country-specific shocks significantly affect current accounts, but global shocks do not (hypotheses H1 to H3); this contradicts to Souki and Enders's (2008) findings that global shocks explain sizable portions of bilateral current accounts ${ }^{9}$. Compared with Souki and Enders's (2008) industrial countries (United States, Germany), 6 Asian economies exhibited similar consumption preferences, technologies, and capital stocks. Global shocks thus equally influenced all countries, exerting little effect on current accounts of specific countries, and supporting Glick and Rogoff's (1995) findings.

Regarding research implication, bridging a gap of mixed evidences in extant research, this paper provides evidences from Asian economies that a country-specific transitory shock primarily affecting current account dominates net output variation, in favor of the intertemporal theory, and provides a resolution of Kano's (2008) second puzzle. This paper is the first original work to examine validity of the PVMCA for Asian countries via conducting SVAR framework. It not only confirms intertemporal theoretical expectation, but proves the validity of PVMCA, which was studied in few researches.

The remainders are organized as follows. Section 1 provides literature review and four hypotheses. Section 2 describes research methodology. Section 3 illustrates data analyses. Section 4 presents results. Final section provides conclusions.

\section{Literature review and hypotheses}

\subsection{Effects of global shocks on current accounts}

Razin (1995), Glick and Rogoff (1995) proposed that, given that all economies are homogeneous, if each economy reacts symmetrically to a global shock, it does not provide consumers an opportunity to smooth their consumption. No economy changes its foreign asset position while facing a global shock because each economy has the same demand for riskless international bonds. In a small open economy, a global shock has no apparent effect on current accounts. Compared with country-specific shocks, global

\footnotetext{
${ }^{9}$ Souki and Enders (2008) stated that, as Glick and Rogoff (1995) implied, a global shock can affect countries asymmetrically and unequally if these countries have different preferences, technologies, and capital stocks.
} 
shocks have little effect on current accounts because they affect all countries equally ${ }^{10}$. Earlier studies confirmed these statements (Kwark 1999; Hoffmann 2001; Nason, Rogers 2002). Under the homogeneity across countries, every economy has the same excess demand for international riskless bonds; no economy alters its foreign asset position following a global shock, because other economies react to shocks symmetrically. A global shock thus has no effects on current accounts (Kano 2008) ${ }^{11}$. Country-specific shocks to productivity and government budget affect current accounts, but global innovations have no effects (Bussière et al. 2010) ${ }^{12}$. In spite of Hoffmann's (2013) findings ${ }^{13}$, most studies support little global effects on current accounts. I proposed first hypotheses as:

H1.1. A global-permanent shock has no significant effects on current accounts in a small open economy.

H1.2. A global-transitory shock has no significant effects on current accounts in a small open economy.

\subsection{Effects of country-specific shocks on current accounts}

Country-specific shocks more substantially affect current accounts than global shocks (Glick, Rogoff 1995; Nason, Rogers 2002). Based on the intertemporal PVMCA, country-specific transitory shocks affect current accounts because consumers need smooth their consumption by borrowing from or lending to the rest of the world. Countryspecific permanent shocks that require long-term consumption changes rather than intertemporal consumption switches should not affect current accounts (Nason, Rogers 2002). Kano (2008) stated that after relaxing assumption of a constant world interest rate, the way country-specific shocks affect current accounts depends on persistence of the shock. Lee and Chinn (2006) determined that a country-specified transitory shock affect current accounts substantially, whereas effect of a country-specified permanent shock is negligible. Bussière et al. (2010) confirmed theoretical prediction that countryspecific shocks in productivity and government budgets affect current accounts, whereas global innovations do not. I thus proposed the hypotheses as:

H2.1. A country-specific permanent shock has neither short- nor long-term significant effects on current accounts in a small open economy.

\footnotetext{
${ }^{10}$ Glick and Rogoff (1995) stated that "if all countries have identical preference, technology, and initial capital stock, then the change in a country's current account depends on its country-specific shock, but not on the global shock, since the latter impacts on all countries equally".

${ }^{11}$ Based on the PVMCA, Kano (2008) estimated SVAR model and provided similar findings for the United Kingdom and Canada.

${ }^{12}$ Bussière et al. (2010) extended the standard intertemporal model of current accounts, deriving cross-equation restrictions for current accounts and investments by identifying the distinctions between country-specific and global innovations to productivity, and government budgets; the extended model is consistent with data spanning from 1960 to 2003 of 21 OECD countries.

${ }^{13}$ Hoffmann (2013) confirmed that the PVMCA explains most variations in Chinese current account, and a global permanent shock is a critical driver in China, consistent with the prediction that factors related to domestic financial development of China are driving the surplus.
} 
H2.2. A country-specific transitory shock has significant short-term effects, but no significant long-term effects on current accounts in a small open economy.

Most studies confirmed that country-specific transitory shocks significantly affect current account, whereas country-specific permanent shocks and global permanent and transitory shocks do not. I thus proposed the following hypothesis:

H3. Current account variations can be primarily attributed to a country-specific transitory shock in a small open economy.

The PVMCA indicates that a current account is determined by expected series of world interest rates, real exchange rates, and growth rates of net output. In terms of variance decomposition, the PVMCA implies that shocks affecting three future variables also significantly affect current accounts. Being not consistent with this, a Kano's (2008) second puzzle indicated that a country transitory shock dominating current account fluctuations explained little variation in net output. To explore this, I proposed final hypothesis as:

H4. Shocks that primarily explain current account variation also dominate the variations in net output, real exchange rates, and world interest rates, or three, in a small open economy.

\section{Research methodology}

\subsection{An intertemporal present value model of current account}

Following Hoffmann (2013) ${ }^{14}$, the intertemporal present value model of current account (PVMCA) is expressed as:

$$
\frac{\tilde{\mathrm{C}} \mathrm{A}_{\mathrm{t}}}{\mathrm{NO}_{\mathrm{t}}}=\mathrm{b} \tilde{\mathrm{r}}_{\mathrm{t}}^{\mathrm{w}}+\left[1-\mathrm{c}\left(1-\frac{1}{\gamma}\right)\right] \sum_{\mathrm{k}=1}^{\infty} \kappa^{\mathrm{k}} \mathrm{E}_{\mathrm{t}} \tilde{\mathrm{r}}_{\mathrm{t}+\mathrm{k}}^{\mathrm{w}}+\mathrm{c}\left(1-\frac{1}{\gamma}\right) \sum_{\mathrm{k}=1}^{\infty} \kappa^{\mathrm{k}} \mathrm{E}_{\mathrm{t}} \Delta \tilde{\mathrm{q}}_{\mathrm{t}+\mathrm{k}}-\sum_{\mathrm{k}=1}^{\infty} \kappa^{\mathrm{k}} \mathrm{E}_{\mathrm{t}} \Delta \tilde{\mathrm{n}} \mathrm{o}_{\mathrm{t}+\mathrm{k}},
$$

where parameters $\mathrm{b}$ and $\mathrm{c}$ denote long-term means of net foreign asset-net output ratio $\left(\mathrm{B}_{\mathrm{t}} / \mathrm{NO}_{\mathrm{t}}\right)$ and consumption-net output ratio $\left(\mathrm{C}_{\mathrm{t}} / \mathrm{NO}_{\mathrm{t}}\right), 1 / \gamma$ is intertemporal elasticity of substitution, and $\kappa$ is a discount factor. Eq. (1) postulates that current account-net output ratio $\frac{\mathrm{CA}_{t}}{\mathrm{NO}_{\mathrm{t}}}$ is primarily determined by three variables on right hand side (RHS) of Eq. (1) (world interest rate $\tilde{r}_{t}^{w}$, real exchange rate $\Delta \tilde{q}_{t+k}$, and growth rate of logarithm net output $\left.\Delta \tilde{\text { ño }} \tilde{t}_{t+k}\right)$; the tilde denotes deviation from the unconditional mean of each variable. This model suggests that $\frac{\mathrm{CA}_{t}}{\mathrm{NO}_{\mathrm{t}}}$ reflects a stationary cointegration relationship among three variables. Thus, $\frac{\mathrm{CA}_{t}}{\mathrm{NO}_{t}}$ should be stationary. Most importantly, the key condition for PVMCA Eq. (1) is to have a cointegration, which allows the use of IRFs and FEVD.

\footnotetext{
${ }^{14}$ Following Bergin and Sheffrin (2000) and Kano (2008), Hoffmann (2013) adopted a time-variant world interest rate assumption. Two variables (real exchange rate and saving wedge) were added to the intertemporal model of current account to derive a present-value representation of the current account-net output ratio, assuming $\tilde{\tau}_{\mathrm{t}}^{\mathrm{s}}=\tilde{\tau}^{\mathrm{s}}=0$.
} 


\subsection{VAR and VMA representation}

To identify four structural shocks via imposing restrictions to test four hypotheses, structural VARs methodology was employed. Following Hoffman (2013), expected variables on the RHS on Eq. (1) were used to construct a vector autoregressive model (VAR). Following Hoffmann (2013), I grouped variables $\Delta \mathrm{r}_{\mathrm{t}}^{\mathrm{w}}, \Delta \mathrm{q}_{\mathrm{t}}, \Delta \ln \mathrm{No}_{\mathrm{t}}$, and $\frac{\mathrm{CA}_{\mathrm{t}}}{\mathrm{NO}_{\mathrm{t}}}$ into a
four-variable VAR in a reduced-form system:

$$
\left[\begin{array}{c}
\Delta \mathrm{r}_{\mathrm{t}}^{\mathrm{W}} \\
\Delta \mathrm{q}_{\mathrm{t}} \\
\Delta \ln \mathrm{NO}_{\mathrm{t}} \\
\frac{\mathrm{CA}_{\mathrm{t}}}{\mathrm{NO}_{\mathrm{t}}}
\end{array}\right]=\left[\begin{array}{llll}
\mathrm{A}_{11}(\mathrm{~L}) & \mathrm{A}_{12}(\mathrm{~L}) & \mathrm{A}_{13}(\mathrm{~L}) & \mathrm{A}_{14}(\mathrm{~L}) \\
\mathrm{A}_{21}(\mathrm{~L}) & \mathrm{A}_{22}(\mathrm{~L}) & \mathrm{A}_{23}(\mathrm{~L}) & \mathrm{A}_{24}(\mathrm{~L}) \\
\mathrm{A}_{31}(\mathrm{~L}) & \mathrm{A}_{32}(\mathrm{~L}) & \mathrm{A}_{33}(\mathrm{~L}) & \mathrm{A}_{34}(\mathrm{~L}) \\
\mathrm{A}_{41}(\mathrm{~L}) & \mathrm{A}_{42}(\mathrm{~L}) & \mathrm{A}_{43}(\mathrm{~L}) & \mathrm{A}_{44}(\mathrm{~L})
\end{array}\right]\left[\begin{array}{c}
\Delta \mathrm{r}_{\mathrm{t}}^{\mathrm{w}} \\
\Delta \mathrm{q}_{\mathrm{t}} \\
\Delta \ln \mathrm{NO}_{\mathrm{t}} \\
\mathrm{CA}_{\mathrm{t}} \\
\mathrm{NO}_{\mathrm{t}}
\end{array}\right]+\left[\begin{array}{c}
\mathrm{e}_{\mathrm{t}}^{\mathrm{r}} \\
\mathrm{e}_{\mathrm{t}}^{\mathrm{q}} \\
\mathrm{e}_{\mathrm{t}}^{\mathrm{no}} \\
\mathrm{e}_{\mathrm{t}}^{\mathrm{ca}}
\end{array}\right] .
$$

The VAR in Eq. (2) in companion-form can be represented as $z_{t}=A(L) z_{t-1}+e_{t}$, where $A_{i j}(L)$ denotes polynomials in the lag operator $L$ of order $k$ for $i, j=1,2,3,4$.

I inverted reduced-form VAR in Eq. (2) to generate a vector moving-average (VMA) representation $z_{t}=R(L) e_{t}$, shown as follows:

$$
\left[\begin{array}{c}
\Delta \mathrm{r}_{\mathrm{t}}^{\mathrm{W}} \\
\Delta \mathrm{q}_{\mathrm{t}} \\
\Delta \ln \mathrm{NO}_{\mathrm{t}} \\
\frac{\mathrm{CA}_{\mathrm{t}}}{\mathrm{NO}_{\mathrm{t}}}
\end{array}\right]=\left[\begin{array}{llll}
\mathrm{R}_{11}(\mathrm{~L}) & \mathrm{R}_{12}(\mathrm{~L}) & \mathrm{R}_{13}(\mathrm{~L}) & \mathrm{R}_{14}(\mathrm{~L}) \\
\mathrm{R}_{21}(\mathrm{~L}) & \mathrm{R}_{22}(\mathrm{~L}) & \mathrm{R}_{23}(\mathrm{~L}) & \mathrm{R}_{24}(\mathrm{~L}) \\
\mathrm{R}_{31}(\mathrm{~L}) & \mathrm{R}_{32}(\mathrm{~L}) & \mathrm{R}_{33}(\mathrm{~L}) & \mathrm{R}_{34}(\mathrm{~L}) \\
\mathrm{R}_{41}(\mathrm{~L}) & \mathrm{R}_{42}(\mathrm{~L}) & \mathrm{R}_{43}(\mathrm{~L}) & \mathrm{R}_{44}(\mathrm{~L})
\end{array}\right]\left[\begin{array}{c}
\mathrm{e}_{\mathrm{t}}^{\mathrm{r}} \\
\mathrm{e}_{\mathrm{t}}^{\mathrm{q}} \\
\mathrm{e}_{\mathrm{t}}^{\mathrm{no}} \\
\mathrm{e}_{\mathrm{t}}^{\mathrm{ca}}
\end{array}\right]
$$

where $\mathrm{R}_{\mathrm{ij}}(\mathrm{L})$ includes reduced-form IRFs influenced by four innovations (world interest rate, real exchange rate, net output, and current account). I used an identification scheme to generate a structural VMA, which provided IRFs influenced by four orthogonal structural shocks. Following Hoffmann (2013), I assumed that this structural VMA contained global permanent shock $\mathrm{e}_{\mathrm{t}}^{\mathrm{GP}}$, global transitory shock $\mathrm{e}_{\mathrm{t}}^{\mathrm{GT}}$, country-specific permanent shock $\mathrm{e}_{\mathrm{t}}^{\mathrm{CP}}$, country-specific transitory shock $\mathrm{e}_{\mathrm{t}}^{\mathrm{CT}}$ :

$$
\left[\begin{array}{c}
\Delta \mathrm{r}_{\mathrm{t}}^{\mathrm{W}} \\
\Delta \mathrm{q}_{\mathrm{t}} \\
\Delta \ln \mathrm{NO}_{\mathrm{t}} \\
\frac{\mathrm{CA}_{\mathrm{t}}}{\mathrm{NO}_{\mathrm{t}}}
\end{array}\right]=\left[\begin{array}{llll}
\mathrm{C}_{11}(\mathrm{~L}) & \mathrm{C}_{12}(\mathrm{~L}) & \mathrm{C}_{13}(\mathrm{~L}) & \mathrm{C}_{14}(\mathrm{~L}) \\
\mathrm{C}_{21}(\mathrm{~L}) & \mathrm{C}_{22}(\mathrm{~L}) & \mathrm{C}_{23}(\mathrm{~L}) & \mathrm{C}_{24}(\mathrm{~L}) \\
\mathrm{C}_{31}(\mathrm{~L}) & \mathrm{C}_{32}(\mathrm{~L}) & \mathrm{C}_{33}(\mathrm{~L}) & \mathrm{C}_{34}(\mathrm{~L}) \\
\mathrm{C}_{41}(\mathrm{~L}) & \mathrm{C}_{42}(\mathrm{~L}) & \mathrm{C}_{43}(\mathrm{~L}) & \mathrm{C}_{44}(\mathrm{~L})
\end{array}\right]\left[\begin{array}{c}
\varepsilon_{\mathrm{t}}^{\mathrm{GP}} \\
\varepsilon_{\mathrm{t}}^{\mathrm{GT}} \\
\varepsilon_{\mathrm{t}}^{\mathrm{CP}} \\
\varepsilon_{\mathrm{t}}^{\mathrm{CT}}
\end{array}\right],
$$

or in companion-form $\mathrm{z}_{\mathrm{t}}=\mathrm{C}(\mathrm{L}) \varepsilon_{\mathrm{t}}$, which supplies the IRFs for $\Delta \mathrm{r}_{\mathrm{t}}^{\mathrm{W}}, \Delta \mathrm{q}_{\mathrm{t}}, \Delta \ln \mathrm{NO}_{\mathrm{t}}$, and $\frac{\mathrm{CA}_{t}}{\mathrm{NO}_{\mathrm{t}}}$ in respond to four structural shocks. I used a standard assumption in international finance that a country-specific shock affects economic variables only in a given country, and a global shock affects those of several countries. Following Souki 
and Enders (2008) $)^{15}$, I add a timing condition of econometric term into this study: a country-specific shock in i need to have no "contemporaneous" effect on other countries, whereas a global shock can affect several countries "simultaneously". It is possible for a country-specific shock in a country to have a lagged effect on other countries (Souki, Enders 2008) ${ }^{16}$. Following Souki and Enders (2008), I classified shocks by their impact scope rather than their regional sources ${ }^{17}$. To assure that country-specific shocks without any immediate worldwide effects are orthogonal to each other and to global shocks, I assumed that $\mathrm{E}\left(\varepsilon_{\mathrm{t}}^{\mathrm{CP}} \varepsilon_{\mathrm{t}}^{\mathrm{CT}}\right)=0, \mathrm{E}\left(\varepsilon_{\mathrm{t}}^{\mathrm{CP}} \varepsilon_{\mathrm{t}}^{\mathrm{GP}}\right)=0, \mathrm{E}\left(\varepsilon_{\mathrm{t}}^{\mathrm{CP}} \varepsilon_{\mathrm{t}}^{\mathrm{GT}}\right)=0, \mathrm{E}\left(\varepsilon_{\mathrm{t}}^{\mathrm{CT}} \varepsilon_{\mathrm{t}}^{\mathrm{GP}}\right)=0$, $\mathrm{E}\left(\varepsilon_{\mathrm{t}}^{\mathrm{CT}} \varepsilon_{\mathrm{t}}^{\mathrm{GT}}\right)=0$.

Based on two criteria-timing and effect scope, I further classify the shocks in hypotheses. Regarding hypothesis H1, following Hoffmann's (2013) global shocks with permanent and transitory types, a shock which affects several countries simultaneously in a short run is classified as a global- transitory shock. Other one with simultaneous effects on several countries in the long run is a global- permanent shock. For hypothesis H2, following Kano (2008) and Hoffmann (2013), I decompose country-specific shocks into transitory and permanent components. The former is a shock which affects current account in country $i$ but no contemporaneous effects on other countries in the short run. The latter is shock with the same effects for the long run.

\subsection{Structural VMA identification}

To identify structural VMA from reduced-form VMA $\left(z_{t}=R(L) e_{t}\right)$, I need 16 equations to solve 16 elements in a $4 \times 4$ matrix $B$ in relation to disturbance terms $\left(e_{t}\right)$ and structural shocks $\left(\varepsilon_{t}\right)$ as follows:

$$
\varepsilon_{\mathrm{t}}=\mathrm{Be}_{\mathrm{t}} \text {. }
$$

I substituted Eq. (5) into the equation $\mathrm{z}_{\mathrm{t}}=\mathrm{R}(\mathrm{L}) \mathrm{e}_{\mathrm{t}}=\mathrm{C}(\mathrm{L}) \varepsilon_{\mathrm{t}}$, generating:

$$
\mathrm{C}(\mathrm{L})=\mathrm{R}(\mathrm{L}) \mathrm{B}^{-1} \text {. }
$$

According to Eq. (6), to obtain structural VMA, a $4 \times 4$ symmetric covariance matrix that comprised structural shocks was approximately equal to identity matrix:

$$
\mathrm{I} \equiv \mathrm{E}\left(\varepsilon_{\mathrm{t}} \varepsilon_{\mathrm{t}}^{\prime}\right)=\mathrm{BE}\left(\mathrm{e}_{\mathrm{t}} \mathrm{e}_{\mathrm{t}}^{\prime}\right) \mathrm{B}^{\prime} \equiv \mathrm{B} \Sigma \mathrm{B}^{\prime}
$$

where Eq. (7) provides 10 restrictive equations to identify the matrix B.

\footnotetext{
${ }^{15}$ Souki and Enders (2008) indicated "In our view, the distinction between country-specific and global shocks should also be made with reference to the timing, and not just the effects of the shocks".

${ }^{16}$ For example, a shock of U.S., which has lagged effects on other countries, would be classified as a country-specific shock, rather than a global shock.

${ }^{17}$ For example, the 9/11 attack in 2001 or an announcement by Microsoft - both of which originated in the U.S. but caused immediate worldwide consequences - are regarded as global shocks. Similarly, the sharp rise in oil prices resulting from the hostilities between Israel and Hezbollah in July 2006 was classified as a global shock rather than an Israel shock. The shock was global because of its consequences around the world, not because of its source. The sharp fall in the oil price thanks to the ceasefire in August 2006 was a positive global shock (Souki, Enders 2008).
} 
To obtain an identified system, imposing of 6 restrictions on structural identification is necessary. The first restriction reflects small open-economy assumption that requires country-specific permanent and transitory shocks to have no long-run effect on world interest rate, respectively (Kano 2008: 765). Therefore, world interest rate $\left(r_{t}{ }^{w}\right)$ is affected in the short- and long-term only by a global permanent shock, whereas other three shocks affect $r_{t}^{\mathrm{W}}$ only in the short term. This is characterized by zero long-term effects of a global transitory shock and two country-specific shocks on $r_{t}^{w}$, as follows:

$$
\mathrm{C}_{12}(1)=\mathrm{C}_{13}(1)=\mathrm{C}_{14}(1)=0 \text { or } \sum_{\mathrm{k}=0}^{\infty} \mathrm{c}_{12}^{\mathrm{k}}=\sum_{\mathrm{k}=0}^{\infty} \mathrm{c}_{13}^{\mathrm{k}}=\sum_{\mathrm{k}=0}^{\infty} \mathrm{c}_{14}^{\mathrm{k}}=0 \text {. }
$$

The second restriction is that real exchange rate $\left(\Delta \mathrm{q}_{\mathrm{t}}\right)$ is affected only in the long run by global shocks. Two country-specific shocks affect $\Delta q_{t}$ only in the short term, and have zero long-term effects on $\Delta \mathrm{q}_{\mathrm{t}}$. They are represented as follows:

$$
\mathrm{C}_{23}(1)=\mathrm{C}_{24}(1)=0 \text { or } \sum_{\mathrm{k}=0}^{\infty} \mathrm{c}_{23}^{\mathrm{k}}=\sum_{\mathrm{k}=0}^{\infty} \mathrm{c}_{24}^{\mathrm{k}}=0 \text {. }
$$

Kano's (2008) hypothesis 3 indicates that impact of country-specific transitory shock on current account-net output ratio is given as the difference between impact of the shock on net output and on consumption (2008: 764). In short run, country-specific transitory shocks should affect current accounts by increasing or reducing net output because consumers need to smooth their consumption by borrowing from or lending to the rest of the world, whereas in the long run, there are no changes in current account, net output and consumption. As Kano's (2008) long-run restriction equation (16), to decompose country-specific shocks into permanent and transitory components, I impose the sixth restriction that a country-specific transitory shock has short-run effects, but no long-run effects on differenced logarithm of net output $\left(\Delta \ln \mathrm{NO}_{\mathrm{t}}\right)$ as:

$$
\mathrm{C}_{34}(1)=0 \text { or } \sum_{\mathrm{k}=0}^{\infty} \mathrm{c}_{34}^{\mathrm{k}}=0 \text {. }
$$

Based on Eq. (8) (10), a long-term VMA representation $\left(\mathrm{z}_{\mathrm{t}}=\mathrm{C}(1) \varepsilon_{\mathrm{t}}\right)$ shows as:

$$
\left[\begin{array}{c}
\Delta \mathrm{r}_{\mathrm{t}}^{\mathrm{W}} \\
\Delta \mathrm{q}_{\mathrm{t}} \\
\Delta \ln \mathrm{NO}_{\mathrm{t}} \\
\frac{\mathrm{CA}_{\mathrm{t}}}{\mathrm{NO}_{\mathrm{t}}}
\end{array}\right]=\left[\begin{array}{cccc}
\mathrm{C}_{11}(\mathrm{~L}) & 0 & 0 & 0 \\
\mathrm{C}_{21}(\mathrm{~L}) & \mathrm{C}_{22}(\mathrm{~L}) & 0 & 0 \\
\mathrm{C}_{31}(\mathrm{~L}) & \mathrm{C}_{32}(\mathrm{~L}) & \mathrm{C}_{33}(\mathrm{~L}) & 0 \\
\mathrm{C}_{41}(\mathrm{~L}) & \mathrm{C}_{42}(\mathrm{~L}) & \mathrm{C}_{43}(\mathrm{~L}) & \mathrm{C}_{44}(\mathrm{~L})
\end{array}\right]\left[\begin{array}{c}
\varepsilon_{\mathrm{t}}^{\mathrm{GP}} \\
\varepsilon_{\mathrm{t}}^{\mathrm{GT}} \\
\varepsilon_{\mathrm{t}}^{\mathrm{CP}} \\
\varepsilon_{\mathrm{t}}^{\mathrm{CT}}
\end{array}\right] .
$$

Long-term form of Eq.(6) is given as:

$$
\mathrm{C}(1) \mathrm{B}=\mathrm{R}(1)
$$

Eq.(10) provides sixth equation for exact identification of matrix B. After completing structural VMA identification, I used Eq.(13) (16) to obtain IRFs and FEVDs of current accounts to four shocks:

$$
\frac{\partial \mathrm{CA}_{\mathrm{t}}}{\partial \varepsilon_{\mathrm{t}-\mathrm{k}}^{\mathrm{GP}}}=\frac{\mathrm{CA}}{(\mathrm{CA} / \mathrm{NO})} \times \frac{\left(\partial \mathrm{CA}_{\mathrm{t}} / \mathrm{NO}_{\mathrm{t}}\right)}{\partial \varepsilon_{\mathrm{t}-\mathrm{k}}^{\mathrm{GP}}}+\mathrm{CA}\left(\frac{\partial \ln \mathrm{NO}_{\mathrm{t}}}{\partial \varepsilon_{\mathrm{t}-\mathrm{k}}^{\mathrm{GP}}}\right)=\frac{\mathrm{CA}}{(\mathrm{CA} / \mathrm{NO})} \times \mathrm{C}_{41}+\mathrm{CA} \times \mathrm{C}_{31}
$$




$$
\begin{aligned}
& \frac{\partial \mathrm{CA}_{\mathrm{t}}}{\partial \varepsilon_{\mathrm{t}-\mathrm{k}}^{\mathrm{GT}}}=\frac{\mathrm{CA}}{(\mathrm{CA} / \mathrm{NO})} \times \frac{\left(\partial \mathrm{CA}_{t} / \mathrm{NO}_{\mathrm{t}}\right)}{\partial \varepsilon_{\mathrm{t}-\mathrm{k}}^{\mathrm{GT}}}+\mathrm{CA}\left(\frac{\partial \operatorname{lnNO}}{\partial \varepsilon_{\mathrm{t}-\mathrm{k}}^{\mathrm{GT}}}\right)=\frac{\mathrm{CA}}{(\mathrm{CA} / \mathrm{NO})} \times \mathrm{C}_{42}+\mathrm{CA} \times \mathrm{C}_{32} ; \\
& \frac{\partial \mathrm{CA}_{\mathrm{t}}}{\partial \varepsilon_{\mathrm{t}-\mathrm{k}}^{\mathrm{CP}}}=\frac{\mathrm{CA}}{(\mathrm{CA} / \mathrm{NO})} \times \frac{\left(\partial \mathrm{CA}_{\mathrm{t}} / \mathrm{NO}_{\mathrm{t}}\right)}{\partial \varepsilon_{\mathrm{t}-\mathrm{k}}^{\mathrm{CP}}}+\mathrm{CA}\left(\frac{\partial \operatorname{lnNO}}{\partial \varepsilon_{\mathrm{t}-\mathrm{k}}^{\mathrm{CP}}}\right)=\frac{\mathrm{CA}}{(\mathrm{CA} / \mathrm{NO})} \times \mathrm{C}_{43}+\mathrm{CA} \times \mathrm{C}_{33} ; \\
& \frac{\partial \mathrm{CA}_{t}}{\partial \varepsilon_{\mathrm{t}-\mathrm{k}}^{\mathrm{CT}}}=\frac{\mathrm{CA}}{(\mathrm{CA} / \mathrm{NO})} \times \frac{\left(\partial \mathrm{CA}_{t} / \mathrm{NO}_{\mathrm{t}}\right)}{\partial \varepsilon_{\mathrm{t}-\mathrm{k}}^{\mathrm{CT}}}+\mathrm{CA}\left(\frac{\partial \ln \mathrm{NO}_{\mathrm{t}}}{\partial \varepsilon_{\mathrm{t}-\mathrm{k}}^{\mathrm{CT}}}\right)=\frac{\mathrm{CA}}{(\mathrm{CA} / \mathrm{NO})} \times \mathrm{C}_{44}+\mathrm{CA} \times \mathrm{C}_{34}
\end{aligned}
$$

\section{Preliminary analysis}

\subsection{Data description}

I collected data from 6 Asian countries, Hong Kong, Japan, Singapore, Taiwan, India, and the Philippines, which were extracted from AREMOS database and International Financial Statistics (IFS) distributed by International Monetary Fund (IMF) ${ }^{18}$. Because of data availability, I selected data including three variables (world interest rate, real exchange rate, net output) with annual and quarterly frequency for a sample period of 1963 2012 (Table 1).

Table 1. Data summary

\begin{tabular}{ccccccc}
\hline Country & Sample period & Frequency & $\begin{array}{c}\text { Current } \\
\text { account }\end{array}$ & $\begin{array}{c}\text { Net } \\
\text { output }\end{array}$ & $\begin{array}{c}\text { World } \\
\text { interest rate }\end{array}$ & $\begin{array}{c}\text { Real exchange } \\
\text { rate }\end{array}$ \\
\hline Honk Kong & 1999Q1 2012Q4 & quarterly & 56 & 56 & 56 & 56 \\
\hline Japan & $1980 Q 1 \sim 2012 Q 4$ & quarterly & 132 & 132 & 132 & 132 \\
\hline Singapore & $1975 Q 1 \sim 2012 Q 4$ & quarterly & 152 & 152 & 152 & 152 \\
\hline Total & & & 340 & 340 & 340 & 340 \\
\hline Taiwan & $1963 Q 1 \sim 2012 Q 4$ & quarterly & 200 & 200 & 200 & 200 \\
\hline India & $1963 \sim 2012$ & yearly & 50 & 50 & 50 & 50 \\
\hline Philippines & $1981 Q 1 \sim 2012 Q 4$ & quarterly & 128 & 128 & 128 & 128 \\
\hline
\end{tabular}

Notes: Table 1 presents the data for six Asian countries during a sample period of 1963 2012. Data are grouped by two subsets: developing countries including Taiwan, the Philippines, and India; developed countries consisting of Hong Kong, Japan, Singapore.

${ }^{18}$ In the AREMOS and IFS databases, South Korea and Indonesia had no abundant data to extract. Therefore, we omitted these two countries because of unavailable data. 
Subsequently, this paper used the weighted average of the quarterly real interest rate ${ }^{19}$ across the G-7 economies to calculate the real world interest rates. The time-varying weights for each country were calculated based on its share of the real GDP in the total GDP of the G-7 economies (i.e., United States, Canada, the United Kingdom, Japan, Germany, France, and Italy). For the robust purpose, this paper further adopts a formula of $[(1+$ normal interest rate $) /(1+$ inflation $)]-1$ to calculate real interest rate ${ }^{20}$. We calculated the net output by subtracting the gross fixed capital formation, change in stocks, and government consumption expenditure from the GDP. The nominal net output was converted to a real series by deflating the GDP deflator. The net output was differenced and taken a logarithm to obtain $\Delta \ln \mathrm{NO}_{\mathrm{t}}$. Current account $\left(\mathrm{CA}_{\mathrm{t}}\right)$ was calculated by subtracting the gross fixed capital formation, change in stocks, government consumption expenditures, and private consumption expenditures from the GNP. We converted current account to a real series by deflating the GDP deflator, and divided the real current account by net output to calculate the current account-net output ratio $\left(\frac{\mathrm{CA}_{t}}{\mathrm{NO}_{\mathrm{t}}}\right)$. Real exchange rate was adjusted by using consumption price index taken from the IFS.

\subsection{Unit root tests}

To ensure that the spurious regression described by Granger and Newbold (1974) generated no problems for the VARs, we first verified that the variables used to estimate our VARs were stationary; therefore, two unit-root tests were used to determine whether the variables in levels or differenced were stationary. This depended on the order of integration of the variables. Table 2 shows the results of augmented Dickey-Fuller (ADF) and Phillips-Perron unit-root tests, which are used to distinguish the variables in level and first differenced. The optimal lag length in the ADF regressions is determined by applying the Akaike information criterion and the Schwartz Bayesian criterion. We plotted the data series in Figure 1 for visual screening and subsequently compared the regressions with and without a constant before choosing a final regression model. Testing results show that the current account $\left(\mathrm{CA}_{t}\right)$ and net output $\left(\mathrm{NO}_{t}\right)$, being seasonally adjusted, are nonstationary, except the $\mathrm{NO}_{t}$ for Japan and Philippine. Globally, we thus infer that $\mathrm{No}_{t}$ and $\mathrm{CA}_{t}$ are $\mathrm{I}(1)$ because their first difference is stationary. The current accountnet output ratio $\left(\frac{\mathrm{CA}_{t}}{\mathrm{NO}_{\mathrm{t}}}\right)$ in level is $\mathrm{I}(0)$, because the unit-root null is rejected ${ }^{21}$. For 6 countries, world interest rate $\left(\mathrm{r}_{\mathrm{t}}^{\mathrm{w}}\right)$ without being seasonally adjusted is nonstationary,

\footnotetext{
${ }^{19}$ Following previous research (e.g., Barro, Sala-i-Martin 1990; Bergin, Sheffrin 2000); Hoffmann 2013; Kano 2008), this paper collects 3-month US T-bill rates or money market rates of the G-7 economies from IFS as nominal interest rates, and subtracted the consumer price index (proxy of inflation rate) to calculate the real interest rate.

${ }^{20}$ The author appreciates first comment from reviewer \#2 providing the formula to calculate real interest rate.

${ }^{21}$ This finding is consistent with the theoretical expectation of PVMCA, which indicates that three I(1) variables of PVMCA, r, q, NO, are cointegrated to obtain current account-net output ratio, being $\mathrm{I}(0)$ series.
} 
and its first difference is stationary; thereby it is inferred to be I(1). Similar to this, real exchange rate $\left(\mathrm{q}_{\mathrm{t}}\right)$ without being seasonally adjusted contains a unit root, and its first difference is stationary; thus it is $\mathrm{I}(1)$.

Table 2. Unit root tests

\begin{tabular}{|c|c|c|c|c|c|c|}
\hline \multirow{2}{*}{ Country } & \multirow{2}{*}{ Variable } & \multicolumn{2}{|r|}{$\mathrm{ADF}$} & \multicolumn{2}{|c|}{ Phillips-Perron } & \multirow[t]{2}{*}{ Test result } \\
\hline & & Level & First difference & Level & First difference & \\
\hline \multicolumn{7}{|c|}{ Developed countries } \\
\hline \multirow[t]{4}{*}{ Hong Kong } & $\mathrm{CA}$ & -1.602 & $-5.996 * * *$ & -0.839 & $-14.475 * * *$ & $\mathrm{I}(\mathrm{I})$ \\
\hline & $\mathrm{NO}$ & -2.884 & $-10.688 * * *$ & -2.889 & $-10.689 * * *$ & $\mathrm{I}(1)$ \\
\hline & $\mathrm{r}$ & -1.067 & $-4.771 * * *$ & -1.082 & $-4.847 * * *$ & $\mathrm{I}(1)$ \\
\hline & q & -2.096 & $-6.029 * * *$ & -2.284 & $-6.035 * * *$ & $\mathrm{I}(1)$ \\
\hline \multirow[t]{4}{*}{ Japan } & $\mathrm{CA}$ & -2.485 & $-8.716^{* * *}$ & -2.496 & $-8.716^{* * *}$ & $\mathrm{I}(1)$ \\
\hline & NO & $-1.669 *$ & - & -3.019 & $-10.998 * * *$ & $\mathrm{I}(0)$ \\
\hline & $\mathrm{r}$ & -1.614 & $-9.125 * * *$ & -1.298 & $-9.145 * * *$ & $\mathrm{I}(1)$ \\
\hline & q & -1.951 & $-10.033 * * *$ & -1.973 & $-10.079 * * *$ & $\mathrm{I}(1)$ \\
\hline \multirow[t]{4}{*}{ Singapore } & $\mathrm{CA}$ & -2.621 & $-14.755^{* * *}$ & -2.521 & $-15.055^{* * *}$ & $\mathrm{I}(1)$ \\
\hline & $\mathrm{NO}$ & -2.748 & $-13.418 * * *$ & -2.626 & $-13.778 * * *$ & $\mathrm{I}(1)$ \\
\hline & $\mathrm{r}$ & -1.366 & $-8.871 * * *$ & -1.312 & $-8.864 * * *$ & $\mathrm{I}(1)$ \\
\hline & q & -1.914 & $-12.262 * * *$ & -1.645 & $-16.395 * * *$ & $\mathrm{I}(1)$ \\
\hline \multicolumn{7}{|c|}{ Developing countries (emerging market) } \\
\hline \multirow[t]{4}{*}{ Taiwan } & $\mathrm{CA}$ & 3.692 & $-14.447 * * *$ & 3.499 & $-14.548 * * *$ & $\mathrm{I}(1)$ \\
\hline & NO & 0.901 & $-15.332 * * *$ & 3.855 & $-16.774 * * *$ & $\mathrm{I}(1)$ \\
\hline & $\mathrm{r}$ & -2.092 & $-9.409 * * *$ & -1.957 & $-9.403^{* * *}$ & $\mathrm{I}(1)$ \\
\hline & $q$ & -1.365 & $-14.035 * * *$ & -1.377 & $-14.035^{* * *}$ & $\mathrm{I}(1)$ \\
\hline \multirow[t]{4}{*}{ India } & $\mathrm{CA}$ & -0.068 & $-8.498 * * *$ & 0.199 & $-8.443 * * *$ & $\mathrm{I}(1)$ \\
\hline & $\mathrm{NO}$ & -1.821 & $-5.841 * * *$ & -1.837 & $-5.892 * * *$ & $\mathrm{I}(1)$ \\
\hline & $\mathrm{r}$ & -1.649 & $-5.364 * * *$ & -1.605 & $-5.229 * * *$ & $\mathrm{I}(1)$ \\
\hline & $q$ & -1.746 & $-8.242 * * *$ & -1.829 & $-8.115 * * *$ & $\mathrm{I}(1)$ \\
\hline \multirow[t]{4}{*}{ Philippines } & CA & -3.007 & $-4.325 * * *$ & -3.763 & $-9.61 * * *$ & $\mathrm{I}(1)$ \\
\hline & NO & $-2.581 *$ & - & $-2.592 *$ & $-10.758 * * *$ & $\mathrm{I}(0)$ \\
\hline & $\mathrm{r}$ & -2.085 & $-8.250 * * *$ & -1.508 & $-8.249 * * *$ & $\mathrm{I}(\mathrm{I})$ \\
\hline & $q$ & -1.845 & $-9.247 * * *$ & -1.739 & $-9.422 * * *$ & $\mathrm{I}(1)$ \\
\hline
\end{tabular}

Notes: $*, * *, * * *$ indicate significant test statistics at $1 \%, 5 \%, 10 \%$ levels. While conducting ADF and PP test, critical statistics of MacKinnon (1991) is used to decide whether unit-root null is rejected. Four variables $\mathrm{CA}_{t}, \mathrm{NO}_{t}, \mathrm{r}_{\mathrm{t}}, \mathrm{q}_{\mathrm{t}}$ represent current accounts, net output, world interest rate, real exchange rate. 

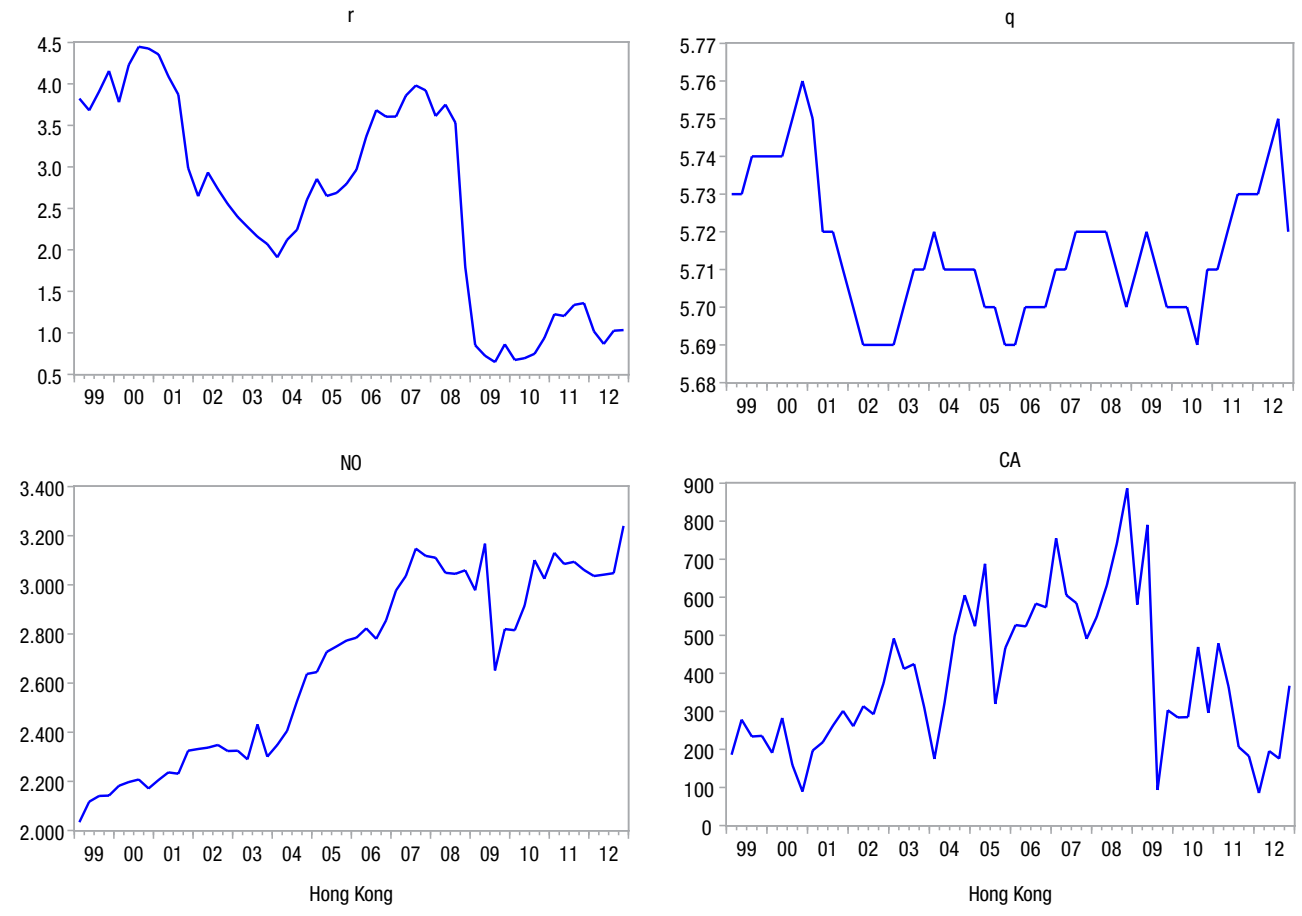

Fig. 1. World interest rate (r), real exchange rate (q), net output (NO), current account (CA) series of Hong Kong over the period 1999Q1 2012Q4

Because the series of Japan and the Philippines have a mixed order of integration, this paper uses Generalized Method of Moments method (hereafter refer to GMM) estimation procedure ${ }^{22}$, similar to Hoffmann (2013)'s method. I designed the programs of four equations including four variables to conduct system estimation with GMM, and get GMM estimators to apply SVAR procedure. The empirical procedure as described in section 3 is introduced for Hong Kong, India, Taiwan and Singapore.

\section{Empirical results and analysis}

\subsection{Dynamic reaction of current accounts to structural shocks}

We first identified the IRFs of $\Delta \mathrm{r}_{\mathrm{t}}^{\mathrm{W}}, \Delta \mathrm{q}_{\mathrm{t}}, \Delta \ln \mathrm{NO}_{\mathrm{t}}, \frac{\mathrm{CA}_{\mathrm{t}}}{\mathrm{NO}_{\mathrm{t}}}{ }^{23}$, and calculated the IRFs of current accounts by using Eq. (13) (16). Figures 3 8 present the accumulated impulse response coefficients, reflecting the accumulated responses of current accounts to four structural shocks. For 6 Asian economies, country-specific transitory shocks produced a

22 The author very appreciates the comment $12^{\text {th }}$ from the reviewer, indicating that a mixed order of integration could influence validity of SVAR. To save space, GMM estimation results are not shown here, but they are available upon request of the readers.

${ }^{23}$ To save space, IRFs figures of four variables to four structural shocks are not completely shown except for Table 4, but are available upon request of the readers. 
stronger impact than did the other three shocks, but in the long term, the responses to the four shocks gradually disappeared, supporting hypothesis H1, H2 and H3. For example, IRF of Hong Kong exhibited the highest unit impact to a country-specific transitory shock at the $17^{\text {th }}$ horizon. Subsequently, by repeated and diminishing oscillations, this response moved toward a long-term level. In sum, the current account of Hong Kong exhibited the most significant response to a country-specific transitory shock; however, little impacts to other three shocks support H1, H2, and H3. Regarding India, countryspecific transitory shocks exhibited the greater effect on current account than the other shocks (Fig. 4), consistent with forecast error variance of current account mainly caused by country-specific transitory shock (Table 3 panel A). This outcome is related to India annual observations. Global transitory, global permanent, and country-specific permanent shocks often do not occur frequently ${ }^{24}$. By contrast, country-specific transitory shocks may take place frequently in India (e.g., productivity risk, poverty, public budget difficulty, earthquake, and typhoon). Year by year, the effects of country-specific transitory shocks on current account appear to be more significant than other three shocks. Similarly, country-specific transitory shocks' effects for Japan are highest comparing to others, being close to 1500 for the long time (Fig. 7) and consistent with forecast error variance of current account mainly caused by country-specific transitory shocks (Table 3 panel B). This may be because that the country-specific transitory shocks occur more frequently in Japan than other shocks.

Table 3. Current account forecast error variance explained by structural shocks for Asian economies

Panel A. Two economies with weaker variance of CA caused by country-specific transitory shocks

\begin{tabular}{ccccc|cccc}
\hline \multirow{2}{*}{$\begin{array}{c}\text { Forecast } \\
\text { Horizon }\end{array}$} & \multicolumn{5}{c}{ Hong Kong } & \multicolumn{4}{c}{ India } \\
\cline { 2 - 9 } & $\varepsilon_{\mathrm{t}}^{\mathrm{GP}}$ & $\varepsilon_{\mathrm{t}}^{\mathrm{GT}}$ & $\varepsilon_{\mathrm{t}}^{\mathrm{CP}}$ & $\varepsilon_{\mathrm{t}}^{\mathrm{CT}}$ & $\varepsilon_{\mathrm{t}}^{\mathrm{GP}}$ & $\varepsilon_{\mathrm{t}}^{\mathrm{GT}}$ & $\varepsilon_{\mathrm{t}}^{\mathrm{CP}}$ & $\varepsilon_{\mathrm{t}}^{\mathrm{CT}}$ \\
\hline 1 & 22.57 & 0.46 & 37.31 & 39.66 & 0.08 & 14.71 & 6.67 & 78.53 \\
\hline 2 & 18.15 & 7.13 & 35.93 & 38.79 & 5.58 & 23.64 & 6.42 & 64.36 \\
\hline 3 & 16.90 & 14.80 & 33.89 & 34.40 & 5.07 & 27.77 & 6.14 & 61.01 \\
\hline 4 & 21.09 & 13.27 & 33.62 & 32.02 & 17.28 & 23.61 & 10.45 & 48.66 \\
\hline 5 & 19.81 & 12.65 & 31.74 & 35.80 & 19.36 & 22.28 & 9.90 & 48.46 \\
\hline 10 & 19.87 & 21.48 & 28.73 & 29.92 & 21.88 & 23.90 & 10.00 & 44.23 \\
\hline 20 & 19.07 & 22.45 & 26.76 & 31.72 & 21.88 & 24.19 & 9.89 & 44.04 \\
\hline 30 & 19.17 & 22.51 & 26.76 & 31.55 & 21.88 & 24.23 & 9.88 & 44.01 \\
\hline 40 & 19.17 & 22.54 & 26.74 & 31.56 & 21.88 & 24.23 & 9.88 & 44.01 \\
\hline 50 & 19.17 & 22.54 & 26.74 & 31.55 & 21.88 & 24.23 & 9.88 & 44.01 \\
\hline
\end{tabular}

${ }^{24}$ For example, in one month, when one of three shocks has negative effects on the current account, current account decreases with the effects; whereas in the next month, another shock positively affects the current account to rise up. Two opposite effects are accumulatively offset each other; overall, in this year, the variation in current account may be zero or a little changes. 
End of Table 3

Panel B. Four economies with stronger variance of CA caused by country-specific transitory shocks

\begin{tabular}{|c|c|c|c|c|c|c|c|c|}
\hline \multirow{2}{*}{$\begin{array}{l}\text { Forecast } \\
\text { Horizon }\end{array}$} & \multicolumn{4}{|c|}{ Taiwan } & \multicolumn{4}{|c|}{ Singapore } \\
\hline & $\varepsilon_{\mathrm{t}}^{\mathrm{GP}}$ & $\varepsilon_{\mathrm{t}}^{\mathrm{GT}}$ & $\varepsilon_{\mathrm{t}}^{\mathrm{CP}}$ & $\varepsilon_{\mathrm{t}}^{\mathrm{CT}}$ & $\varepsilon_{\mathrm{t}}^{\mathrm{GP}}$ & $\varepsilon_{\mathrm{t}}^{\mathrm{GT}}$ & $\varepsilon_{\mathrm{t}}^{\mathrm{CP}}$ & $\varepsilon_{t}^{C T}$ \\
\hline 1 & 0.92 & 10.00 & 35.05 & 54.02 & 6.23 & 4.52 & 7.32 & 81.94 \\
\hline 2 & 2.09 & 10.06 & 32.88 & 54.96 & 10.57 & 4.20 & 8.66 & 76.57 \\
\hline 3 & 2.13 & 10.14 & 34.27 & 53.46 & 9.10 & 4.98 & 7.48 & 78.43 \\
\hline 4 & 2.88 & 10.19 & 34.54 & 52.39 & 8.41 & 5.66 & 7.16 & 78.77 \\
\hline 5 & 4.42 & 10.20 & 34.22 & 51.15 & 8.23 & 6.85 & 7.03 & 77.88 \\
\hline 10 & 4.50 & 10.22 & 34.27 & 51.01 & 16.21 & 6.15 & 6.20 & 71.44 \\
\hline 20 & 4.51 & 10.22 & 34.27 & 51.00 & 13.64 & 6.93 & 5.34 & 74.09 \\
\hline 30 & 4.51 & 10.22 & 34.27 & 51.00 & 12.61 & 6.95 & 4.94 & 75.51 \\
\hline 40 & 4.51 & 10.22 & 34.27 & 51.00 & 12.16 & 6.98 & 4.77 & 76.09 \\
\hline 50 & 4.51 & 10.22 & 34.27 & 51.00 & 11.96 & 6.99 & 4.69 & 76.36 \\
\hline \multirow{2}{*}{$\begin{array}{l}\text { Forecast } \\
\text { Horizon }\end{array}$} & \multicolumn{4}{|c|}{ Japan } & \multicolumn{4}{|c|}{ Philippine } \\
\hline & $\varepsilon_{\mathrm{t}}^{\mathrm{GP}}$ & $\varepsilon_{\mathrm{t}}^{\mathrm{GT}}$ & $\varepsilon_{\mathrm{t}}^{\mathrm{CP}}$ & $\varepsilon_{\mathrm{t}}^{\mathrm{CT}}$ & $\varepsilon_{\mathrm{t}}^{\mathrm{GP}}$ & $\varepsilon_{\mathrm{t}}^{\mathrm{GT}}$ & $\varepsilon_{\mathrm{t}}^{\mathrm{CP}}$ & $\varepsilon_{\mathrm{t}}^{\mathrm{CT}}$ \\
\hline 1 & 19.86 & 9.31 & 14.89 & 55.94 & 4.06 & 6.99 & 0.45 & 88.50 \\
\hline 2 & 18.06 & 13.92 & 16.23 & 51.79 & 6.48 & 10.21 & 5.36 & 77.96 \\
\hline 3 & 17.80 & 13.73 & 17.32 & 51.15 & 6.58 & 11.12 & 10.05 & 72.26 \\
\hline 4 & 17.69 & 13.96 & 17.60 & 50.75 & 6.52 & 11.82 & 13.41 & 68.24 \\
\hline 5 & 17.77 & 13.92 & 17.77 & 50.54 & 6.39 & 12.06 & 15.55 & 65.99 \\
\hline 10 & 17.74 & 14.05 & 17.88 & 50.33 & 6.19 & 12.26 & 17.98 & 63.57 \\
\hline 20 & 17.77 & 14.04 & 17.90 & 50.29 & 6.25 & 12.26 & 18.03 & 63.46 \\
\hline 30 & 17.79 & 14.04 & 17.89 & 50.28 & 6.38 & 12.23 & 18.07 & 63.31 \\
\hline 40 & 17.81 & 14.03 & 17.89 & 50.27 & 6.47 & 12.22 & 18.07 & 63.24 \\
\hline 50 & 17.81 & 14.03 & 17.89 & 50.27 & 6.52 & 12.21 & 18.07 & 63.20 \\
\hline
\end{tabular}

Notes: Current account FEVDs are calculated from the IRFs of current account, which in turn are obtained from the IRFs of $\Delta \mathrm{r}_{\mathrm{t}}^{\mathrm{w}}, \Delta \mathrm{q}_{\mathrm{t}}, \Delta \ln \mathrm{No}_{\mathrm{t}}, \frac{\mathrm{CA}_{\mathrm{t}}}{\mathrm{NO}_{\mathrm{t}}}$ using Eqs. (13) (16). Notations $\varepsilon_{\mathrm{t}}^{\mathrm{GP}}, \varepsilon_{\mathrm{t}}^{\mathrm{GT}}, \varepsilon_{\mathrm{t}}^{\mathrm{CP}}$, $\varepsilon_{\mathrm{t}}^{\mathrm{CT}}$ represent the global-permanent shock, global-transitory shock, country-specific permanent shock, and country- specific transitory shock.

IRF figures of 6 economies show that current accounts displayed a slight positive or negative hump pattern in response to global permanent and transitory shocks in the short term, supporting H1.1and H1.2. India shows that a global-permanent shock initially caused a little increase in current account and a slight decline in world interest rate at the $3^{\text {th }}$ horizon (see Figs 2 and 4). This shock also caused the same direction of change 
in exchange rates and current accounts, suggesting a positive relationship between exchange rates and current accounts for Japan (see Figs 2 and 4) ${ }^{25}$.

For the long time, about the case of India where the global permanent and transitory effects are quasi-equivalent (Table 3 panel A). Forecast error variance decompositions (FEVDs) are calculated from accumulative impulse responses of current account to shocks. In IRF of India (Fig. 4), absolute values of two effects are almost equal to 5, but two values' signs are contrary. These findings may be coincidences stemming from calculation procedures. The effect-values of accumulative impulse responses of current account to shocks are calculated by the sum of the effect-values of current period and previous periods. For example, for the long time, global permanent effect -0.5 is negative net value of subtracting accumulative positive value from accumulative negative value, implying that the negative effect-value of global permanent shock is -0.5. (e.g., 2007 subprime mortgage crisis, 2009 European sovereign debt crisis). By contrast, for the long time, global transitory effect 0.5 is positive net value of subtracting accumulative negative value from accumulative positive value, implying that the positive effectvalue of global transitory shock is 0.5 . (e.g., oil prices fall down temporarily).
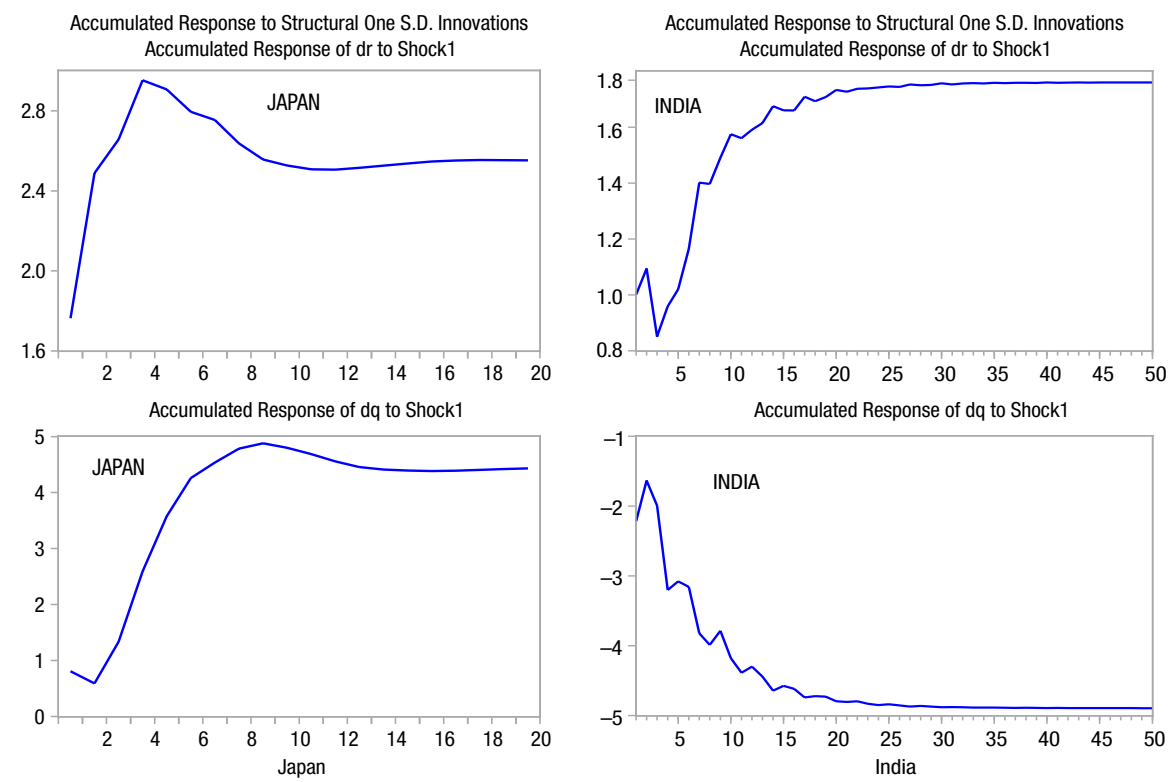

Fig. 2. Accumulated IRFs of world interest rate (r) and real exchange rate (q) in response to a global permanent shock (shock1)

${ }^{25}$ Other countries show that exchange rates and current accounts exhibited no obvious correlation, because a global permanent shock causes exchange rates to fluctuate irregularly, yielding no consistent trends with current account. To save the space, this paper does not display these figures, but they are available upon request of readers. 


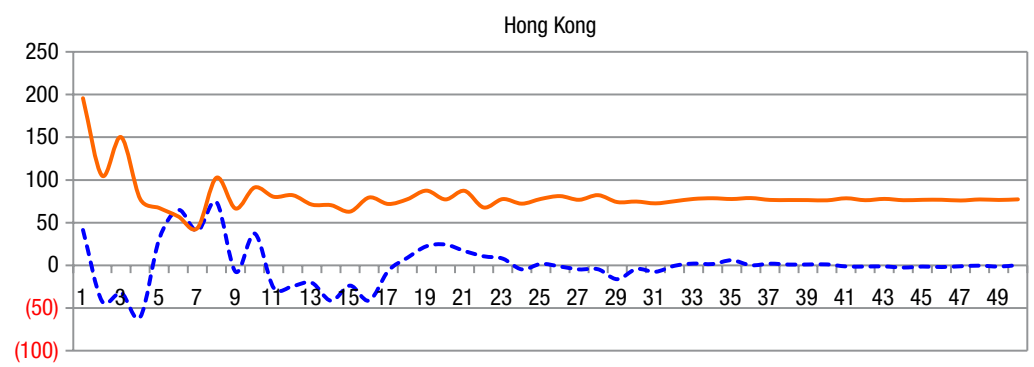

Fig. 3.1. Accumulative response of current account to global permanent shock (blue dotted line), country permanent shock (orange solid line)

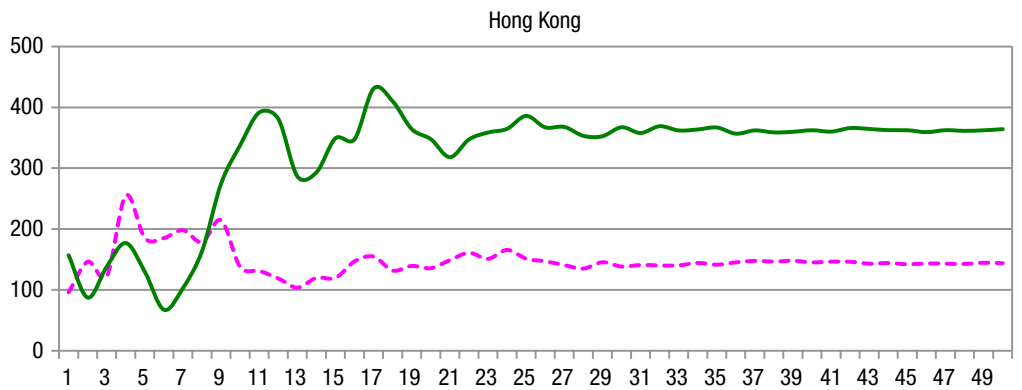

Fig. 3.2. Accumulative response of current account to global transitory shock (pink dotted line), country transitory shock (green solid line)

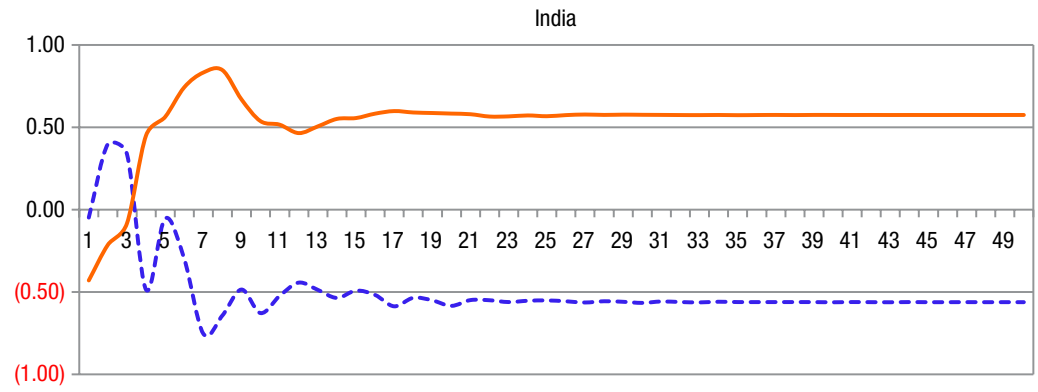

Fig. 4.1. Accumulative current account response to global permanent shock (blue dotted line), country permanent shock (orange solid line)

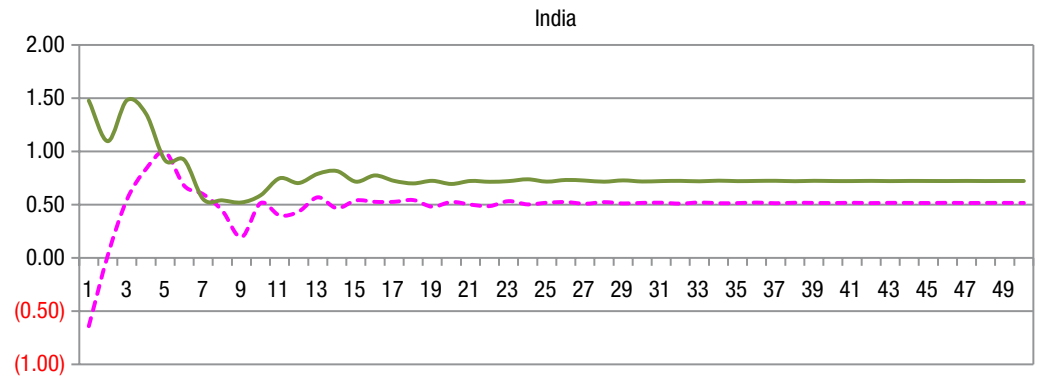

Fig. 4.2. Accumulative current account response to global transitory shock (pink dotted line), country transitory shock (green solid line) 
Singapore

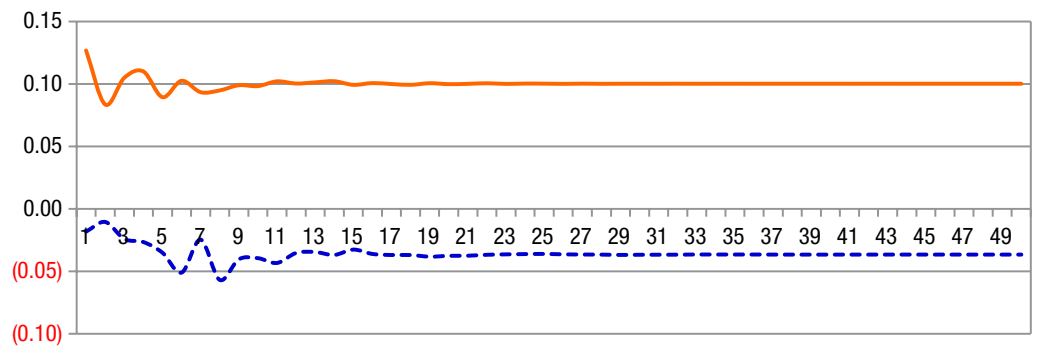

Fig. 5.1. Accumulative response of current account to global permanent shock (blue dotted line), country permanent shock (orange solid line)

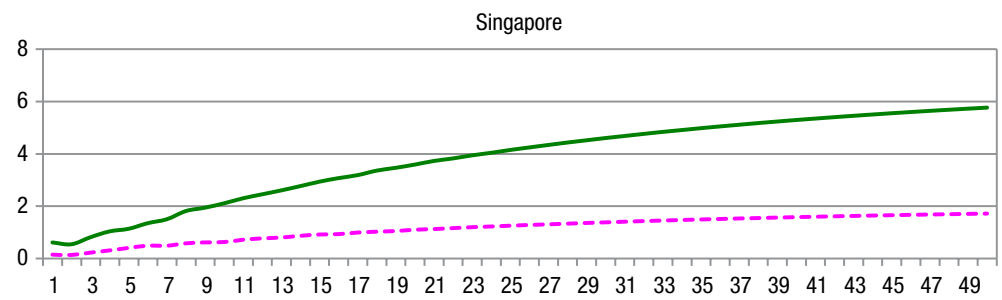

Fig. 5.2. Accumulative response of current account to global transitory shock (pink dotted line), country transitory shock (green solid line)

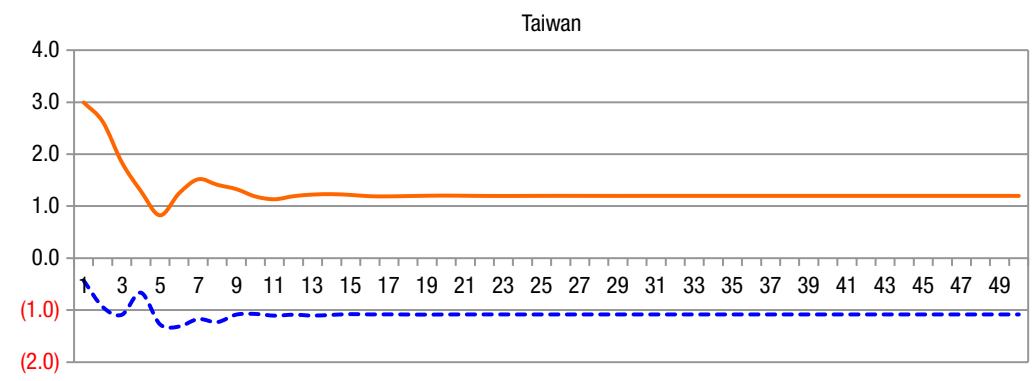

Fig. 6.1. Accumulative response of current account to global permanent shock (blue dotted line), country permanent shock (orange solid line)

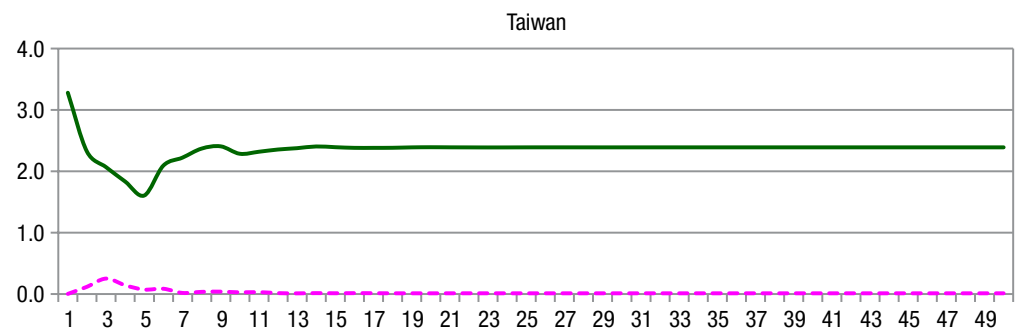

Fig. 6.2. Accumulative response of current account to global transitory shock (pink dotted line), country transitory shock (green solid line) 


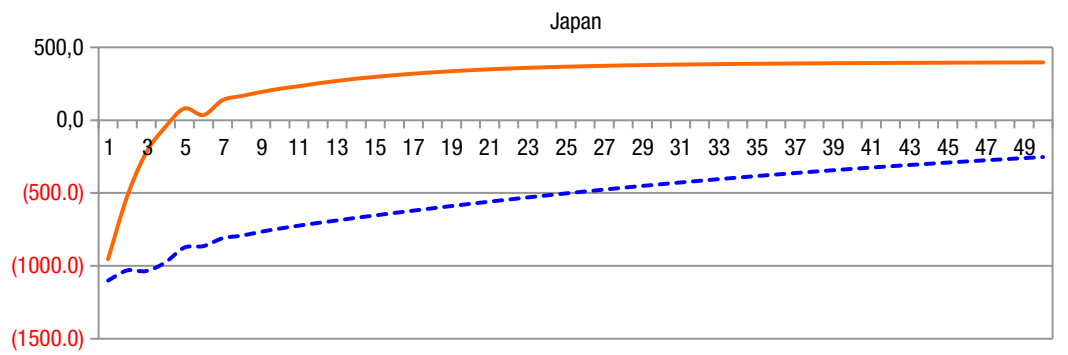

Fig. 7.1. Accumulative response of current account to global permanent shock (blue dotted line), country permanent shock (orange solid line)

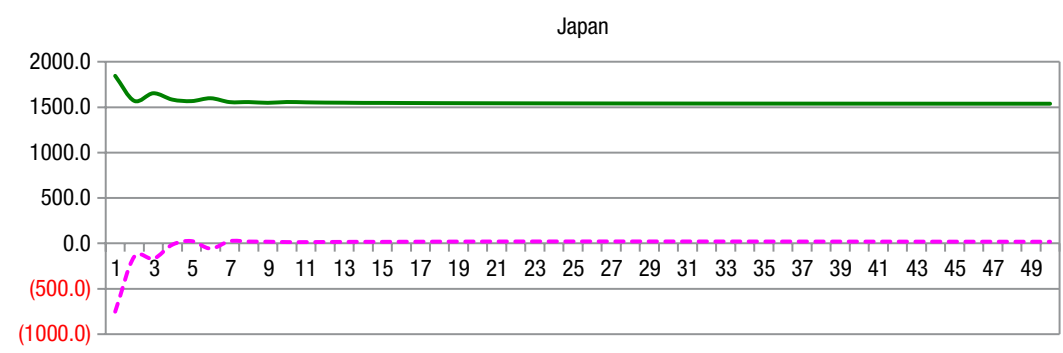

Fig. 7.2. Accumulative response of current account to global transitory shock (pink dotted line), country transitory shock (green solid line)

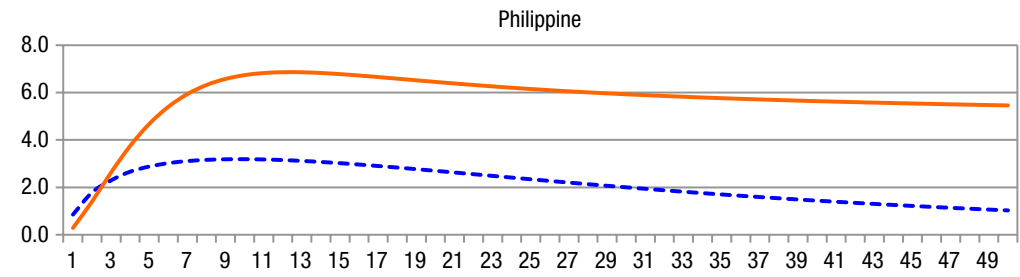

Fig. 8.1. Accumulative response of current account to global permanent shock (blue dotted line), country permanent shock (orange solid line)

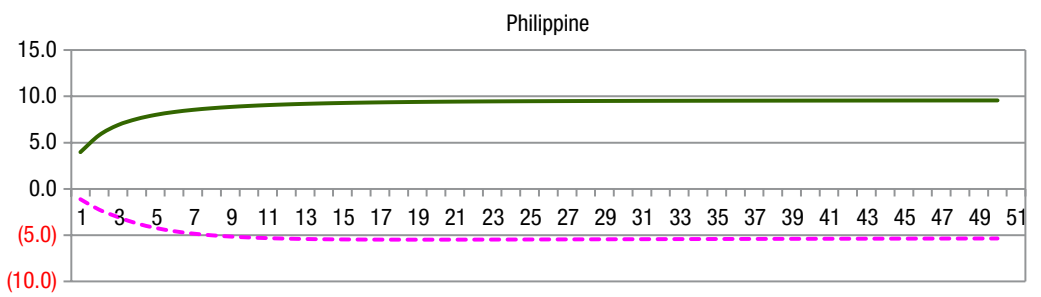

Fig. 8.2. Accumulative response of current account to global transitory shock (pink dotted line), country transitory shock (green solid line) 


\subsection{Current account variation explained by structural shocks}

Table 3 presents the FEVDs of current account variation of 6 Asian countries. They are organized differently by grouping two economies with weaker variance of CA caused by country-specific transitory shocks (panel A), and four economies with stronger variance of CA caused by country-specific transitory shocks (panel B). The empirical findings from 6 countries support hypotheses $\mathrm{H} 1, \mathrm{H} 2$, and $\mathrm{H} 3$, demonstrating that country-specific transitory shocks significantly affected current accounts, whereas the other shocks did not. $31-40 \%, 50-56 \%, 44-79 \%, 63-89 \%, 51-55 \%$, and $71-82 \%$ of the current account variance, were primarily explained by country-specific transitory shocks respectively for Hong-Kong, Japan, India, the Philippines, Taiwan, and Singapore (see Table 3). Regarding India, country-specific transitory shocks exhibited the greater effect on current account than other shocks, dominating the net output variation by contrast to the puzzle of Kano (2008), who stated that country-specific-transitory shocks explained little of the net output variance. Moreover, global transitory and permanent shocks that secondarily affected current accounts explained $52 \sim 61 \%$ of the world interest rate and $65 \sim 74 \%$ of the exchange rate variance (see Table 4 ). The three shocks (country-specific transitory, global-transitory and global-permanent) explained 44\%, 24\%, and 21\% of current account variance approximately (Table 3). By inspecting the forecast error variances, the three shocks that primarily explained current account variances dominated the variation in net output, world interest rates, and exchange rate, supporting $\mathrm{H} 4$ and implying that the PVMCA explanatory variables contained sufficient information to explain current account variations. Accordingly, we verified the validity of PVMCA for India.

Concerning Hong Kong, Singapore, and Taiwan, country-specific transitory shock exerted the greatest effect on current accounts, explaining most of the net output variance and contradicting the puzzle of Kano (2008). Global permanent and transitory shocks which respectively dominated world interest rates and exchange rates (see Table 4), totally explained $41 \%, 20 \%$, and $15 \%$ of the current account variance for Hong Kong, Singapore, and Taiwan, respectively (see Table 3). The three shocks (country-specific transitory, global-transitory, global-permanent) which primarily explained current account variance, dominated the variation in net output, world interest rates, and exchange rate, supporting $\mathrm{H} 4$.

Concerning the remaining two countries (Japan, the Philippines), a country-specific transitory shock explained most of the current account variation, accounting for 50$56 \%, 63-89 \%$ over the entire period, in support of $\mathrm{H} 3$. Moreover, the shock significantly affected current accounts (see Table 3), but failed to dominate the variation in net output (see Table 4). Global permanent and transitory shocks dominated world interest rate and exchange rate respectively, explaining little of the current account variations and failing to support $\mathrm{H} 4$.

Overall, the 6 Asian economies consistently supported the assumption of previous studies that country-specific shocks significantly affect current accounts, whereas global shocks do not. This finding contradicts the empirical results of Souki and Enders (2008), who stated that global shocks explain substantial variation in current accounts. Unlike 
Table 4. Forecast error variance decomposition (FEVD) of four variable (world interest rates, exchange rates, net output, and a ratio of current account to net output) explained by four structural shocks for Asian countries

\begin{tabular}{|c|c|c|c|c|c|c|c|c|c|c|c|c|c|c|c|c|}
\hline \multirow{2}{*}{$\begin{array}{l}\text { Forecast } \\
\text { Horizon }\end{array}$} & \multicolumn{4}{|c|}{$\Delta \mathrm{r}$} & \multicolumn{4}{|c|}{$\Delta \mathrm{q}$} & \multicolumn{4}{|c|}{$\Delta \ln \mathrm{NO}$} & \multicolumn{4}{|c|}{$\mathrm{CA} / \mathrm{NO}$} \\
\hline & $\varepsilon_{\mathrm{t}}^{\mathrm{GP}}$ & $\varepsilon_{\mathrm{t}}^{\mathrm{GT}}$ & $\varepsilon_{t}^{C P}$ & $\varepsilon_{t}^{C T}$ & $\varepsilon_{t}^{\mathrm{GP}}$ & $\varepsilon_{\mathrm{t}}^{\mathrm{GT}}$ & $\varepsilon_{t}^{C P}$ & $\varepsilon_{\mathrm{t}}^{\mathrm{CT}}$ & $\varepsilon_{\mathrm{t}}^{\mathrm{GP}}$ & $\varepsilon_{t}^{G T}$ & $\varepsilon_{t}^{C P}$ & $\varepsilon_{t}^{\mathrm{CT}}$ & $\varepsilon_{\mathrm{t}}^{\mathrm{GP}}$ & $\varepsilon_{\mathrm{t}}^{\mathrm{GT}}$ & $\varepsilon_{t}^{C P}$ & $\varepsilon_{\mathrm{t}}^{\mathrm{CT}}$ \\
\hline \multicolumn{17}{|c|}{ Hong Kong } \\
\hline 1 & 90.33 & 0.91 & 5.73 & 3.02 & 4.58 & 92.10 & 3.19 & 0.12 & 27.08 & 0.26 & 2.69 & 69.96 & 1.74 & 0.37 & 46.62 & 51.26 \\
\hline 2 & 79.29 & 9.87 & 6.91 & 3.92 & 6.38 & 89.59 & 3.82 & 0.20 & 20.22 & 14.28 & 3.68 & 61.82 & 1.74 & 13.64 & 39.21 & 45.40 \\
\hline 5 & 66.27 & 18.20 & 7.38 & 8.14 & 10.59 & 81.11 & 6.73 & 1.56 & 27.50 & 22.93 & 2.97 & 46.60 & 6.47 & 15.67 & 38.01 & 39.83 \\
\hline 10 & 55.52 & 22.35 & 5.31 & 16.82 & 13.38 & 67.69 & 11.27 & 7.65 & 24.93 & 27.12 & 6.48 & 41.46 & 9.16 & 25.54 & 30.21 & 35.09 \\
\hline 30 & 53.50 & 23.38 & 5.78 & 17.33 & 13.63 & 66.01 & 11.99 & 8.37 & 23.92 & 28.65 & 9.66 & 37.76 & 9.11 & 25.96 & 32.34 & 32.59 \\
\hline 50 & 53.47 & 23.42 & 5.78 & 17.31 & 13.65 & 65.97 & 11.99 & 8.38 & 23.91 & 28.68 & 9.69 & 37.72 & 9.11 & 25.96 & 32.33 & 32.57 \\
\hline \multicolumn{17}{|l|}{ India } \\
\hline 1 & 37.68 & 60.98 & 1.32 & 0.00 & 73.95 & 18.93 & 0.19 & 6.91 & 8.73 & 18.11 & 13.42 & 59.72 & 0.52 & 13.17 & 11.09 & 75.21 \\
\hline 2 & 34.26 & 55.07 & 1.22 & 9.43 & 67.99 & 16.49 & 0.45 & 15.05 & 17.82 & 14.42 & 21.61 & 46.15 & 4.85 & 23.91 & 9.17 & 62.05 \\
\hline 5 & 26.31 & 53.85 & 4.19 & 15.64 & 65.74 & 19.46 & 2.67 & 12.12 & 17.51 & 15.56 & 25.73 & 41.19 & 19.65 & 23.20 & 10.88 & 46.26 \\
\hline 10 & 25.37 & 52.75 & 6.29 & 15.56 & 65.42 & 19.95 & 2.93 & 11.69 & 17.72 & 21.40 & 23.26 & 37.60 & 22.69 & 24.25 & 10.85 & 42.19 \\
\hline 30 & 25.09 & 52.52 & 6.28 & 16.09 & 65.56 & 19.75 & 3.03 & 11.65 & 18.49 & 21.64 & 22.64 & 37.22 & 22.67 & 24.56 & 10.72 & 42.04 \\
\hline 50 & 25.09 & 52.52 & 6.28 & 16.09 & 65.56 & 19.75 & 3.03 & 11.65 & 18.49 & 21.64 & 22.64 & 37.22 & 22.67 & 24.56 & 10.72 & 42.04 \\
\hline \multicolumn{17}{|c|}{ Singapore } \\
\hline 1 & 86.71 & 3.80 & 2.31 & 7.18 & 3.70 & 89.44 & 1.00 & 5.86 & 1.96 & 6.92 & 5.95 & 85.17 & 7.02 & 3.72 & 14.25 & 75.01 \\
\hline 2 & 86.35 & 3.76 & 2.32 & 7.56 & 3.57 & 85.24 & 5.68 & 5.51 & 7.02 & 4.59 & 9.92 & 78.46 & 10.52 & 3.54 & 14.46 & 71.48 \\
\hline 5 & 77.96 & 4.27 & 8.90 & 8.87 & 5.54 & 82.28 & 6.67 & 5.51 & 7.60 & 5.06 & 9.46 & 77.87 & 7.64 & 6.91 & 10.61 & 74.83 \\
\hline 10 & 73.28 & 4.86 & 12.36 & 9.50 & 6.31 & 79.91 & 6.88 & 6.90 & 25.73 & 4.47 & 8.68 & 61.12 & 12.63 & 6.98 & 8.13 & 72.26 \\
\hline 30 & 72.36 & 5.25 & 12.79 & 9.61 & 7.18 & 78.52 & 6.92 & 7.38 & 26.98 & 5.03 & 9.57 & 58.41 & 9.01 & 7.50 & 5.73 & 77.75 \\
\hline 50 & 72.34 & 5.25 & 12.79 & 9.62 & 7.19 & 78.52 & 6.92 & 7.38 & 26.98 & 5.04 & 9.57 & 58.41 & 8.45 & 7.52 & 5.38 & 78.65 \\
\hline \multicolumn{17}{|l|}{ Taiwan } \\
\hline 1 & 80.73 & 1.19 & 6.66 & 11.42 & 0.17 & 97.80 & 1.31 & 0.72 & 1.93 & 0.32 & 18.49 & 79.26 & 1.09 & 0.00 & 43.67 & 55.25 \\
\hline 2 & 84.14 & 0.98 & 5.49 & 9.39 & 0.36 & 97.48 & 1.41 & 0.76 & 3.41 & 0.32 & 19.78 & 76.49 & 2.23 & 0.07 & 41.55 & 56.16 \\
\hline 5 & 81.26 & 1.03 & 6.28 & 11.43 & 2.03 & 94.76 & 2.02 & 1.19 & 5.44 & 0.72 & 21.98 & 71.87 & 4.53 & 0.20 & 43.08 & 52.18 \\
\hline 10 & 80.25 & 1.06 & 6.46 & 12.22 & 2.08 & 94.35 & 2.07 & 1.50 & 5.54 & 0.71 & 22.27 & 71.47 & 4.61 & 0.22 & 43.14 & 52.03 \\
\hline 30 & 80.23 & 1.07 & 6.46 & 12.24 & 2.08 & 94.33 & 2.08 & 1.51 & 5.55 & 0.71 & 22.27 & 71.46 & 4.61 & 0.22 & 43.15 & 52.01 \\
\hline 50 & 80.23 & 1.07 & 6.46 & 12.24 & 2.08 & 94.33 & 2.08 & 1.51 & 5.55 & 0.71 & 22.27 & 71.46 & 4.61 & 0.22 & 43.15 & 52.01 \\
\hline \multicolumn{17}{|l|}{ Japan } \\
\hline 1 & 85.86 & 3.05 & 2.55 & 8.54 & 0.04 & 69.82 & 29.06 & 1.07 & 1.08 & 0.31 & 93.45 & 5.16 & 19.94 & 9.53 & 15.00 & 55.53 \\
\hline 2 & 89.74 & 6.32 & 0.97 & 2.97 & 0.04 & 69.52 & 28.86 & 1.58 & 3.97 & 0.79 & 90.90 & 4.34 & 18.16 & 14.05 & 16.31 & 51.48 \\
\hline 5 & 94.26 & 4.19 & 0.54 & 1.01 & 0.52 & 67.52 & 28.49 & 3.47 & 9.95 & 1.56 & 85.10 & 3.38 & 17.86 & 14.04 & 17.85 & 50.24 \\
\hline 10 & 96.80 & 2.01 & 0.70 & 0.49 & 0.58 & 66.81 & 29.17 & 3.44 & 15.40 & 1.37 & 80.58 & 2.64 & 17.84 & 14.17 & 17.97 & 50.03 \\
\hline 30 & 98.32 & 1.02 & 0.43 & 0.24 & 1.10 & 66.24 & 29.24 & 3.41 & 28.70 & 1.11 & 68.09 & 2.10 & 17.89 & 14.15 & 17.98 & 49.98 \\
\hline 50 & 98.55 & 0.87 & 0.38 & 0.20 & 1.29 & 66.11 & 29.19 & 3.41 & 32.84 & 1.05 & 64.14 & 1.98 & 17.91 & 14.15 & 17.97 & 49.97 \\
\hline \multicolumn{17}{|c|}{ Philippines } \\
\hline 1 & 68.46 & 21.09 & 10.41 & $\overline{0.04}$ & 18.24 & 75.33 & 0.29 & $\overline{6.14}$ & 6.81 & 4.99 & 68.44 & 19.76 & 3.88 & 7.05 & 0.19 & 88.89 \\
\hline 2 & 66.32 & 17.43 & 16.22 & 0.02 & 17.58 & 75.51 & 0.56 & 6.36 & 8.77 & 5.33 & 46.79 & 39.10 & 6.18 & 10.38 & 3.92 & 79.52 \\
\hline 5 & 70.26 & 7.61 & 22.01 & 0.12 & 17.40 & 75.23 & 1.12 & 6.24 & 7.72 & 3.43 & 72.76 & 16.08 & 6.07 & 12.59 & 11.52 & 69.83 \\
\hline 10 & 75.30 & 5.09 & 19.42 & 0.18 & 17.40 & 75.23 & 1.12 & 6.24 & 10.97 & 2.51 & 75.84 & 10.69 & 5.91 & 12.94 & 12.82 & 68.33 \\
\hline 30 & 80.82 & 3.75 & 15.28 & 0.15 & 17.41 & 74.98 & 1.29 & 6.32 & 26.09 & 1.96 & 64.29 & 7.67 & 7.23 & 12.67 & 13.21 & 66.88 \\
\hline 50 & 80.91 & 3.68 & 15.26 & 0.15 & 17.43 & 74.96 & 1.30 & 6.32 & 27.17 & 1.93 & 63.37 & 7.53 & 7.40 & 12.65 & 13.22 & 66.74 \\
\hline
\end{tabular}

Notes: Forecast error variance decomposition (FEVD) of four variables, including world interest rates $\left(\Delta r_{t}^{W}\right)$, exchange rates $\left(\Delta \mathrm{q}_{\mathrm{t}}\right)$, net output $\left(\Delta \ln \mathrm{No}_{\mathrm{t}}\right)$, a ratio of current account to net output $\left(\frac{\mathrm{CA}_{\mathrm{t}}}{\mathrm{NO}_{\mathrm{t}}}\right)$. Notations $\varepsilon_{\mathrm{t}}^{\mathrm{GP}}, \varepsilon_{\mathrm{t}}^{\mathrm{GT}}, \varepsilon_{\mathrm{t}}^{\mathrm{CP}}, \varepsilon_{\mathrm{t}}^{\mathrm{CT}}$, represent the global-permanent shock, global-transitory shock, country-specific permanent shock, and country-specific transitory shock. 
Souki and Enders (2008) who analyzed large industrial countries, the United States and Germany, our 6 Asian countries have similar preferences, technologies, and capital stock markets. Thus, global shocks affected all countries, and had little effects on current account of a single country, supporting viewpoint of Glick and Rogoff (1995).

\section{Conclusions}

In lieu of the cross-equation restriction tests used in previous studies, we adopted the SVAR framework to examine the validity of the modified PVMCA developed by Hoffmann (2013). Findings of 4 small open Asian economies (Hong Kong, India, Taiwan and Singapore) support theoretical expectations, indicating that a country-specific transitory shock that most significantly affected current account variation dominates net output variation. The finding provides a resolution of Kano (2008)'s second puzzle indicating that net output is a crucial determinant of current accounts, in favor of consumption-smoothing behavior. Moreover, global-permanent and transitory shocks that secondarily affected current accounts dominate fluctuations in world interest rates and exchange rates. Three shocks (country-specific transitory, global-permanent and transitory shocks) explain most of current account variances. 4 Asian economies' findings support the validity of the PVMCA via proving that its three explanatory variables contain sufficient information to explain current account variations.

Regarding a practical implication, investors can apply PVMCA to forecast changes in current accounts and exchange rates; they can further judge business risks stemming from the changes, and adjust their security portfolio. Country-specific shocks in this study may be not concrete, because they include a variety of impulses affecting variations in current account. Because of this limitation, future research can divide countryspecific shocks as productivity and government budget shocks to examine the validity of the PVMCA. Another direction for future research is to use OECD or industrialized countries as samples to investigate and compare their findings with those of Asian economies.

\section{Acknowledgements}

I am thankful to anonymous referees for their insightful comments and suggestions to improve this paper.

\section{References}

Aizenman, J.; Jinjarak, Y. 2014. Real estate valuation, current account and credit growth patterns, before and after the 2008-2009 crisis, Journal of International Money and Finance 48: 249-270. http://dx.doi.org/10.1016/j.jimonfin.2014.05.016

Bergin, P. R.; Sheffrin, S. M. 2000. Interest rates, exchange rates and present value models of the current account, The Economic Journal 110(April): 535-558.

http://dx.doi.org/10.1111/1468-0297.00536

Barro, R. J.; Sala-i-Martin, X. 1990. World real interest rates, in O. J. Blanchard, S. Fischer (Eds.). NBER macroeconomics annual, Vol. 5. Cambridge, MA: MIT Press. 
Baharumshah, A. Z.; Ismail, H. B. 2012. The present value model and Thailand's current account balance, Journal of Economic Studies 39(3): 337-355. http://dx.doi.org/10.1108/01443581211245919 Blanchard, O. J.; Quah, D. 1989. The dynamic effects of aggregate demand and supply disturbances, American Economic Review 79(4): 655-673.

Blankenau, W.; Kose, M. A.; Yi, K. M. 2001. Can world real interest rates explain business cycles in a small open economy? Journal of Economic Dynamics and Control 25(6-7): 867-889. http://dx.doi.org/10.1016/S0165-1889(00)00059-2

Bussière, M.; Fratzscher, M.; Müller, G. J. 2010. Productivity shocks, budget deficits and the current account, Journal of International Money and Finance 29: 1562-1579.

http://dx.doi.org/10.1016/j.jimonfin.2010.05.012

Buiter, W. H. 1981. Time preference and international lending and borrowing in an overlapping generations model, Journal of Political Economy 89(Aug.): 769-797.

http://dx.doi.org/10.1086/261002

Brissimis, S. N. G.; Papazoglou, H. C.; Tsaveas, N. T.; Vasardani, M. A. 2012. Current account determinants and external sustainability in periods of structural change, Economic Change and Restructuring 45(1-2): 71-95. http://dx.doi.org/10.1007/s10644-011-9107-y

Campbell, J. Y. 1987. Does saving anticipate declining labor income? An alternative test of the permanent income hypothesis, Econometrica 55(6): 1249-1273. http://dx.doi.org/10.2307/1913556

Campbell, J. Y.; Shiller, R. J. 1987. Cointegration and tests of present value model, Journal of Political Economy 95(5): 1062-1088. http://dx.doi.org/10.1086/261502

Cerrato, M.; Kalyoncu, H.; Hassan, N. N.; Tsoukis, C. 2014. Current accounts in the long run and the intertemporal approach: a panel data investigation, World Economy 38(2): 340-359.

http://dx.doi.org/10.1111/twec.12152

Ca'Zorzi, M.; Rubaszek, M. 2012. On the empirical evidence of the intertemporal current account model for the euro area countries, Review of Development Economics 16(1): 95-106.

http://dx.doi.org/10.1111/j.1467-9361.2011.00648.x

Elliott, G.; Fatas, A. 1996. International business cycles and the dynamics of current account, European Economic Review 40: 361-387. http://dx.doi.org/10.1016/0014-2921(95)00123-9

Ghosh, A. R. 1995. International capital mobility amongst the major industrialised countries: too little or too much? The Economic Journal 105: 107-128. http://dx.doi.org/10.2307/2235322

Glick, R.; Rogoff, K. 1995. Global versus country-specific productivity shocks and the current account, Journal of Monetary Economics 35(1): 159-192.

http://dx.doi.org/10.1016/0304-3932(94)01181-9

Gruber, J. W. 2004. A present value test of habits and the current account, Journal of Monetary Economics 51(7): 1495-1507. http://dx.doi.org/10.1016/j.jmoneco.2003.12.004

Granger, C. W. J.; Newbold, P. 1974. Spurious regression in econometrics, Journal of Econometrics 2(2): 111-120. http://dx.doi.org/10.1016/0304-4076(74)90034-7

Hoffmann, M. 2001. The relative dynamics of investment and the current account in G7 economies, Economic Journal 111(471): 148-163. http://dx.doi.org/10.1111/1468-0297.00625

Hoffmann, M. 2013. What drive China's current account?, Journal of International Money and Finance 32: 856-883. http://dx.doi.org/10.1016/j.jimonfin.2012.07.005

Iscan, T. B. 2003. Present value test of the current account with durable consumption, Journal of International Money and Finance 21(3): 1495-1507.

Kano, T. 2008. A structural VAR approach to the intertemporal model of the current account, Journal of International Money and Finance 27: 757-779.

http://dx.doi.org/10.1016/j.jimonfin.2008.04.003

Kim, S.; Lee, J. W. 2007. Demographic changes, saving, and current account in East Asian, Asian Economic Papers 6(2): 22-53. http://dx.doi.org/10.1162/asep.2007.6.2.22 
Kwark, N. S. 1999. Sources of international business fluctuations: country-specific shocks or worldwide shocks?, Journal of International Economics 48(2): 367-385.

http://dx.doi.org/10.1016/S0022-1996(98)00050-6

Lee, J.; Chinn, M. D. 2006. Current account and real exchange rate dynamics in the G7 countries, Journal of International Money and Finance 25: 257-274.

http://dx.doi.org/10.1016/j.jimonfin.2005.11.002

Luo, Y.; Nie, J.; Young, E. R. 2012. Robustness, information-processing constraints, and the current account in small open economies, Journal of International Economics 88(1): 104- 120. http://dx.doi.org/10.1016/j.jinteco.2012.02.004

Moccero, D. N. 2007. The intertemporal approach to the current account: evidence from Argentina, Journal of Applied Economics XI(2): 327-353.

Nason, J. M.; Rogers, J. H. 2002. Investment and the current account in the short run and the long run, Journal of Money, Credit, and Banking 34(4): 967-986.

http://dx.doi.org/10.1353/mcb.2002.0057

Nason, J. M.; Rogers, J. H. 2006. The present-value model of the current account has been rejected: round up the usual suspects, Journal of International Economics 68(1): 159-187.

Narayan, S. 2013. A structural VAR model of the Fiji Islands, Economic Modelling 31: 238-244. http://dx.doi.org/10.1016/j.econmod.2012.11.014

Obstfeld, M.; Rogoff, K. 1995. The intertemporal approach to the current account, in G. M. Grossman, K. Rogoff (Eds.), Handbook of international economics, vol. 3. New York: North Holland Publishing Co., 1731-1799.

Obstfeld, M. 1996. Capital mobility and the world economy: theory and measurement, CarnegieRochester Conference Series on Public Policy 24: 55-104.

http://dx.doi.org/10.1016/0167-2231(86)90005-9

Otto, G. 1992. Testing a present-value model of the current account: evidence from US and Canadian time series, Journal of International Money and Finance 11(5): 414-430.

http://dx.doi.org/10.1016/0261-5606(92)90009-M

Razin, A. 1995. The dynamic-optimizing approach to the current account: theory and evidence, National Bureau of Economic Research, No. w4334.

Sheffrin, S. M.; Woo, W. T. 1990. Present value tests of an intertemporal model of the current account, Journal of International Economics 29(3-4): 237-253.

http://dx.doi.org/10.1016/0022-1996(90)90032-H

Souki, K.; Enders, W. 2008. Assessing the importance of global shocks versus country-specific shocks, Journal of International Money and Finance 27: 1420-1429.

http://dx.doi.org/10.1016/j.jimonfin.2008.07.002

Sachs, J. D. 1981. The current account and macroeconomic adjustment in the 1970s, Brookings Papers on Economic Activity 12: 201-268. http://dx.doi.org/10.2307/2534399

Schubert, S. F. 2014. Dynamic effects of oil price shocks and their impact on the current account, Macroeconomic Dynamics 18(2): 316-337. http://dx.doi.org/10.1017/S1365100512000405

Chen-Yin KUO is an Assistant Professor in Tung Fang Design Institute. She received PhD. degree from Graduate Institute of Business Administration in National Chung Cheng University, Taiwan, R.O.C. Her research interests include financial economic, financial management, corporate valuation, international finance, managerial economic. 